\title{
Using demographic data to understand the distribution of H1N1 and COVID-19 pandemics cases among federal entities and municipalities of Mexico
} \footnotetext{
Jiménez $^{6}$, Clemente Mosso $^{1}$, Arit De León-Lorenzana ${ }^{7}$, Carmine Fusaro $^{\text {Corresp. } 8}$

${ }^{1}$ Centro Regional de Investigación en Salud Pública, Instituto Nacional de Salud Pública, Tapachula, Chiapas, Mexico

2 Facultad de Ingeniería y Ciencias Básicas, Fundación Universitaria del Área Andina, Valledupar, César, Colombia

3 Facultad de Medicina, Universidad del Sinú, Cartagena de Indias, Bolívar, Colombia

4 Dipartimento di Ingegneria Ambientale, Università della Calabria, Rende, Calabria, Italy

5 Facultad de Ingeniería Ambiental, Universidad Popular Autónoma del Estado de Puebla, Puebla, Puebla, Mexico

6 Facultad de Ciencias Químicas, Universidad Veracruzana, Orizaba, Veracruz, Mexico

7 Instituto de Ecología, Universidad Nacional Autónoma de México, Mérida, Yucatán, Mexico

8 Facultad de Ingenierías, Universidad de San Buenaventura - Cartagena, Cartagena de Indias, Bolívar, Colombia

Corresponding Author: Carmine Fusaro

Email address: cafu18685@gmail.com
}

Yohanna Sarria-Guzmán ${ }^{1,2}$, Jaime Bernal ${ }^{3}$, Michele De Biase ${ }^{4}$, Ligia C. Muñoz-Arenas ${ }^{5}$, Francisco Erik González-

Background: the novel coronavirus disease (COVID-19) pandemic is the second global health emergency the world has faced in less than two decades, after the H1N1 Influenza pandemic in 2009-2010. Spread of pandemics is frequently associated with increased population size and population density. The geographical scales (national, regional or local scale) are key elements in determining the correlation between demographic factors and the spread of outbreaks. The aims of this study were: a) to collect the Mexican data related to the two pandemics; b) to create thematic maps using federal and municipal geographic scales; c) to investigate the correlations between the pandemics indicators (numbers of contagious and deaths) and demographic patterns (population size and density).

Methods: the demographic patterns of all Mexican Federal Entities and all municipalities were taken from the database of "Instituto Nacional de Estadística y Geografía" (INEGI). The data of "Centro Nacional de Programas Preventivos y Control de Enfermedades" (CENAPRECE) and the geoportal of Mexico Government were also used in our analysis. The results are presented by means of tables, graphs and thematic maps. A Spearman correlation was used to assess the associations between the pandemics indicators and the demographic patterns. Correlations with a $p$ value $<0.05$ were considered significant.

Results: the confirmed cases (ccH1N1) and deaths (dH1N1) registered during the H1N1 Influenza pandemic were 72.4 thousand and 1244 respectively. Mexico City (CDMX) was the most affected area by the pandemic with $8502 \mathrm{ccH} 1 \mathrm{~N} 1$ and $152 \mathrm{dH} 1 \mathrm{~N} 1$. The ccH1N1 
and dH1N1 were positively correlated to demographic patterns; $p$-values higher than the level of marginal significance were found analyzing the \% $\mathrm{CCH} 1 \mathrm{~N} 1$ and the $\% \mathrm{dH} 1 \mathrm{~N} 1$ versus the population density. The COVID-19 pandemic data indicated 75.0 million confirmed cases (ccCOVID-19) and 1.6 million deaths (dCOVID-19) as of date. The CDMX, where 264330 infections were recorded, is the national epicenter of the pandemic. The federal scale did not allow to observe the correlation between demographic data and pandemic indicators; hence the next step was to choose a more detailed geographical scale (municipal basis). The ccCOVID-19 and dCOVID-19 (municipal basis) were highly correlated with demographic patterns; also the \% ccCOVID-19 and \% dCOVID-19 were moderately correlated with demographic patterns. Conclusion: the magnitude of COVID-19 pandemic is much greater than H1N1 Influenza pandemic. The CDMX was the national epicenter in both pandemics. The federal scale did not allow to evaluate the correlation between exanimated demographic variables and the spread of infections, but the municipal basis allowed the identification of local variations and "red zones" such as the delegation of Iztapalapa and Gustavo A. Madero in CDMX. 


\section{Using demographic data to understand the}

2 distribution of H1N1 and COVID-19 pandemics cases

3 among federal entities and municipalities of Mexico

4

\section{Yohanna Sarria-Guzmán ${ }^{1,2}$, Jaime E. Bernal ${ }^{3}$, Michele De Biase ${ }^{4}$, Ligia C. Muñoz-Arenas ${ }^{5}$,} Francisco Erik González-Jiménez ${ }^{6}$, Clemente Mosso-González ${ }^{1}$, Arit S. De León-Lorenzana ${ }^{7}$, and Carmine Fusaro ${ }^{8}$

${ }^{1}$ Centro Regional de Investigación en Salud Pública, Instituto Nacional de Salud Pública, Tapachula, Chiapas, Mexico

${ }^{2}$ Facultad de Ingeniería y Ciencias Básicas, Fundación Universitaria del Área Andina, Valledupar, César, Colombia

${ }^{3}$ Facultad de Medicina, Universidad del Sinú, Cartagena de Indias, Bolívar, Colombia

${ }^{4}$ Dipartimento di Ingegneria Ambientale, Università della Calabria, Rende, Calabria, Italy

${ }^{5}$ Facultad de Ingeniería Ambiental, Universidad Popular Autónoma del Estado de Puebla, Puebla, Puebla, Mexico

${ }^{6}$ Facultad de Ciencias Químicas, Universidad Veracruzana, Orizaba, Veracruz, Mexico

${ }^{7}$ Instituto de Ecología, Universidad Nacional Autónoma de México, Mérida, Yucatán, Mexico

${ }^{8}$ Facultad de Ingenierías, Universidad de San Buenaventura - Cartagena, Cartagena de Indias, Bolívar, Colombia

Corresponding author

Carmine Fusaro

Facultad de Ingenierías, Universidad de San Buenaventura, Calle Real de Ternera No. 30 - 966, Cartagena de Indias, 130010, Bolívar, Colombia, cafu18685@gmail.com

\section{ABSTRACT}

Background: the novel coronavirus disease (COVID-19) pandemic is the second global health emergency the world has faced in less than two decades, after the H1N1 Influenza pandemic in 2009-2010. Spread of pandemics is frequently associated with increased population size and population density. The geographical scales (national, regional or local scale) are key elements in determining the correlation between demographic factors and the spread of outbreaks. The aims of this study were: a) to collect the Mexican data related to the two pandemics; b) to create thematic maps using federal and municipal geographic scales; c) to investigate the correlations between the pandemics indicators (numbers of contagious and deaths) and demographic patterns (population size and density).

Methods: the demographic patterns of all Mexican Federal Entities and all municipalities were taken from the database of "Instituto Nacional de Estadística y Geografía" (INEGI). The data of 
"Centro Nacional de Programas Preventivos y Control de Enfermedades" (CENAPRECE) and the geoportal of Mexico Government were also used in our analysis. The results are presented by means of tables, graphs and thematic maps. A Spearman correlation was used to assess the associations between the pandemics indicators and the demographic patterns. Correlations with a $p$ value $<0.05$ were considered significant.

Results: the confirmed cases (ccH1N1) and deaths (dH1N1) registered during the H1N1 Influenza pandemic were 72.4 thousand and 1244 respectively. Mexico City (CDMX) was the most affected area by the pandemic with $8502 \mathrm{ccH} 1 \mathrm{~N} 1$ and $152 \mathrm{dH} 1 \mathrm{~N} 1$. The ccH1N1 and dH1N1 were positively correlated to demographic patterns; $p$-values higher than the level of marginal significance were found analyzing the $\% \mathrm{ccH} 1 \mathrm{~N} 1$ and the $\% \mathrm{dH} 1 \mathrm{~N} 1$ versus the population density. The COVID-19 pandemic data indicated 75.0 million confirmed cases (ccCOVID-19) and 1.6 million deaths (dCOVID-19) as of date. The CDMX, where 264330 infections were recorded, is the national epicenter of the pandemic. The federal scale did not allow to observe the correlation between demographic data and pandemic indicators; hence the next step was to choose a more detailed geographical scale (municipal basis). The ccCOVID-19 and dCOVID-19 (municipal basis) were highly correlated with demographic patterns; also the \% ccCOVID-19 and \% dCOVID-19 were moderately correlated with demographic patterns. Conclusion: the magnitude of COVID-19 pandemic is much greater than H1N1 Influenza pandemic. The CDMX was the national epicenter in both pandemics. The federal scale did not allow to evaluate the correlation between exanimated demographic variables and the spread of infections, but the municipal basis allowed the identification of local variations and "red zones" such as the delegation of Iztapalapa and Gustavo A. Madero in CDMX.

\section{Subjects Biogeography, Epidemiology}

Keywords H1N1 Influenza pandemic, COVID-19 pandemic, Mexico, Population size, Population density

\section{INTRODUCTION}

Disease outbreaks have frequently occurred in human history and have had significant impacts on many sectors such as public health, political and economic systems at a local and global scale. The novel coronavirus disease (COVID-19) pandemic is the second global health emergency that governments, health organizations and citizens worldwide have faced over the last two decades (https://www.who.int).

The widely known as "Swine flu", the first influenza pandemic of the 21 century, occurred in 2009-2010 (https://www.cdc.gov) caused by the virus A (H1N1) pdm09; the novel virus presented genetic material from human, pig and bird flu viruses. It was very different from H1N1 viruses formerly identified and, therefore, vaccination of seasonal flu offered little crossprotection (Fraser et al., 2009; Lim \& Mahmood, 2011). Most young people did not show immunity to this virus (Crum-Cianflone et al., 2009), but around one-third of the elderly manifested antibodies probably acquired from exposure to other H1N1 virus in their youth (https://www.cdc.gov). The symptoms of the Influenza A (H1N1) 2009 in people have ranged from mild to severe and include fever, cough, sore throat, nose, body aches, headache, chills, 
81 fatigue, diarrhea and vomiting (Witkop et al., 2010; Petrova \& Russell, 2018; Saunders-Hastings

82 et al., 2017). There were approx. 2.8 million Influenza cases and between 151.7 thousand to

83575.4 thousand deaths worldwide (April 2009 - April 2010) mostly people younger than 65

84

85

86

87

88

89

90

91

92

93

94

95

96

97

98

99

100

101

102

103

104

105

106

107

108

109

110

111

112

113

114

115

116

117

118

119

120 years (https://www.cdc.gov). Many countries, especially in Africa and Southeast Asia, lacked the ability to perform detection tests and still today, there is no certainty about factual pandemic deaths (https://www.who.int). Mexico was among the first countries to notify the World Health Organization (WHO) of viral respiratory disease "Swine flu" and was, also, one of the most affected nations by this pandemic (Kain \& Fowler, 2019; https://www.cdc.gov). The H1N1 Influenza confirmed cases (ccH1N1) were approx. 72.4 thousand while the deaths $(\mathrm{dH} 1 \mathrm{~N} 1)$ were 1244 (data updated to 10 ${ }^{\text {th }}$ April, 2010) (http://www.cenaprece.salud.gob.mx/). On August 10 ${ }^{\text {th }}$ of 2010, the WHO declared the end of sanitary emergency related to Influenza A (H1N1) 2009 pandemic. However, the A (H1N1) pdm09 virus continues to circulate as a seasonal flu virus causing several hospitalizations and deaths in many developing countries every year (https://www.who.int).

At the end of 2019, cases of pneumonia associated with the novel coronavirus (SARS-CoV-2) were reported in the Chinese province of Wuhan. The SARS-CoV-2 is the seventh member of the coronavirus family to infect humans. It is characterized by prolonged incubation time and shedding from asymptomatic patients (Widders, Broom \& Broom, 2020). The COVID-19 outbreak spread quickly worldwide avoiding medical control and it was declared pandemic by the WHO on the $11^{\text {th }}$ of March 2020 (https://www.who.int). The SARS-CoV-2 infected patients are mostly asymptomatic or experience mild symptoms such as fever, dry cough, and sore throat (Ma et al., 2020). However, some patients, principally advanced age people or individuals with comorbities, develop severe and even fatal medical complications (Mehta et al., 2020; Sohrabi et al., 2020).

Risk factors and health conditions that could aggravate the clinical picture of patients with COVID-19 include hypertension, diabetes, cardiovascular disease, chronic respiratory disease, chronic kidney disease, immune compromised status, neurological disorders, cancer, smoking and obesity (Alqahtani et al., 2020; Nieman \& Wentz, 2019; Roncon et al., 2020). People with diabetes increased the odds to develop severe symptoms or die from COVID-19 by 2.7

(Williamson et al., 2020). Patients that suffer from hypertension, cardiovascular or cerebrovascular disease were up to three times more likely to have severe COVID-19 symptoms than people in good health (Wang et al., 2020). Williamson et al. (2020) suggested that the risk of mortality from COVID-19 increase in patients with asthma or respiratory disease. The risk of severe symptoms or death from COVID-19 significantly increase in people with cancer, moreover, among patients with blood cancers the mortality rate is twice that of patients with solid tumors (Meng et al., 2020). According to Simonnet et al. (2020) people that suffer from obesity increase seven times the odds of developing severe COVID-19.

Environmental issues such as air pollution could compromise lung function, and consequently increase the vulnerability to respiratory infections such as COVID-19. It has been proved that other local factors such us overcrowded areas, frequent social interactions and full public 
121 transport can increase the number of contagious by SARS-CoV-2 due its mechanism of

122 transmission; the virus can persist in aerosols and surfaces. With this in mind, the proximity and

123

124

125

126

127

128

129

130

131

132

133

134

135

136

137

138

139

140

141

142

143

144

145

146

147

148

149

150

151

152

153

154

155

156

157

158

159 contact among citizens result key determinants (Meyerowitz et al., 2021; Jordan 2020).

The incidence and morbidity of COVID-19 were different among countries and even regions of the same country, probably due to the different implementation and timing of mitigation strategies adopted by governments (social distancing, travel restrictions and quarantine) (Gerli et $a l ., 2020)$ and social demographic indicators (population density, poverty and unemployment) (Ramírez \& Lee, 2020). The SARS-CoV-2 has infected more than 75.0 million people and we have approx. 1.6 million deaths worldwide by COVID-19 disease as of $18^{\text {th }}$ December, 2020 (https://coronavirus.jhu.edu/map.html). The WHO indicates Latin America as "red zone" of coronavirus transmissions in the world ( $3^{\text {rd }}$ June, 2020). More specifically, in Mexico the ccCOVID-19 (1.2 million) and dCOVID-19 (115.1 thousand) are inexorably increasing day by day (data updated to $16^{\text {th }}$ December, 2020) (https://coronavirus.gob.mx/datos/).

Spread of infectious diseases is frequently associated with increase in population size, population density, aged population density and construction land area (Vazquez-Prokopec et al., 2010; Barreto et al., 2011; Fang et al., 2012; Pequeno et al., 2020; Poole, 2020; Rodrigue, Luke \& Osterholm, 2020; Verity et al., 2020). Epidemics in smaller cities are generally focused on a shorter period (Dalziel et al., 2018), while the incidence is diffuse in the bigger urban areas leading to more interaction among local residents, workers and tourist which make them potential hotspots for pandemics spread; therefore, communication routes such as national highways or freeways, and public transport i.e. subway, buses and trams could magnify the impact of the outbreaks. Understanding the spatial distribution of the COVID-19 confirmed cases (ccCOVID-19), COVID-19 deaths (dCOVID-19) and their association with demographic factors can benefit to isolate the areas of highest risk of infection and the most vulnerable groups of the population at local scale. The geographical scales (national, regional or local scale) are key elements in determining the correlations between demographic factors and spread of outbreaks.

The aims of this article were: a) to collect the official Mexican data (counts of confirmed cases and deaths) related to the H1N1 Influenza pandemic (Centro Nacional de Programas Preventivos y Control de Enfermedades - CENAPRECE, 2010) and the official governmental data related to the COVID-19 pandemic (https://coronavirus.gob.mx/datos/) both on a federal and municipal scale; b) to produce thematic maps (population size - confirmed cases, population size - deaths); c) to investigate the correlations between the pandemics indicators and demographic patterns.

\section{MATERIALS \& METHODS}

\section{Country context}

Mexico is constituted by thirty-two Federal Entities (FEs) and covers a geographical area of $1964375 \mathrm{~km}^{2}$. It is the second most populated country in Latin America after Brazil. Its population, that has increased in the last ten years $(+13.72 \%)$, passing from 112.34 to 127.79 
160 million inhabitants, is mainly grouped in urban areas. All of FEs have reported an upward trend,

161

162

163

164

165

166

167

168

169

170

171

172

173

174

175

176

177

178

179

180

181

182

183

184

185

186

187

188

189

190

191

192

193

194

195

196

197 although the increase in population has been slower than in the first decade of this century.

The population density (2020) varied significantly among the FEs and ranged between 11 inhabitants per $\mathrm{km}^{2}$ (hab. $/ \mathrm{km}^{2}$ ) in Baja California Sur and $6033 \mathrm{hab} . / \mathrm{km} 2$ in Mexico City (CDMX). The capital is far more crowded than any other city in Mexico and is one of the most populated cities in North America, with 9.02 million inhabitants distributed in the "relatively small" surface area of $1495 \mathrm{~km}^{2}$. Its population density is higher than the national average (65 hab./ $\left.\mathrm{km}^{2}\right)$; in particular, the delegations of Iztapalapa (1.82 million hab.) and Gustavo A. Madero (1.18 million hab.) are among the most overpopulated areas in the world. The state of Mexico $\left(22351 \mathrm{~km}^{2}\right)$, in the central part of the country, neighboring with CDMX, is the most populated among the FEs (17.43 million hab. -780 hab. $/ \mathrm{km}^{2}$ ), its inhabitants are concentrated mainly in the cities of Ecatepec de Morelos (1.71 million hab.) and Nezahualcóyotl (1.13 million hab.). Tlaxcala, although is the second smallest Mexican State in size $\left(4016 \mathrm{~km}^{2}\right)$, is in the fourth position in the ranking of the most densely populated places of the republic $\left(344 \mathrm{hab} . / \mathrm{km}^{2}\right)$. Its residents live mostly in Tlaxcala city (103435 hab.). Guerrero (63596 km² - 3.66 million hab.) in the Pacific coast and Yucatan (39524 km² - 2.26 million hab.) in the Gulf of Mexico reported a population density concordant with the national average. Acapulco de Juárez (840795 hab.) and Merida (963861 hab.) are the urban areas more populated in addition to being among the significant national and international tourist destinations. Baja California Sur $\left(73909 \mathrm{~km}^{2}-\right.$ 804708 hab.) in the Pacific coast and Durango (123317 km² -1.87 million hab.) in the central part of the country are among the least populated FEs, with population density about five times lower than the national average.

The demographic patterns i.e. population size (hab.), population density (hab./ $\mathrm{km}^{2}$ ) and surface $\left(\mathrm{km}^{2}\right)$ characteristics of each one of thirty-two FEs and all Mexican municipalities were taken from the database of "Instituto Nacional de Estadística y Geografía" of Mexico (INEGI) (https://www.inegi.org.mx/app/areasgeograficas/). The topographic map (scale 1:250000) updated to 2018 was adopted as cartographic base (http://www.conabio.gob.mx/informacion/gis/).

\section{Pandemics data}

As stated before, risk factors that could aggravate the symptoms derived by COVID-19 include hypertension, diabetes, chronic respiratory or cardiovascular disease, immune compromised status, neurological disorders, cancer, smoking and obesity (Alqahtani et al., 2020; Nieman \& Wentz, 2019; Roncon et al., 2020). In addition, various factors such overcrowded areas, frequent social interactions, full public transport, poor attention to preventive measures in particular disrespect the social distancing could be involved in the growth of the number of contagious during pandemics, which cause the collapse of the national health system and the drastic reduction in the number of ICUs available in Mexican hospitals.

Peer) reviewing PDF | (2020:10:53392:2:0:NEW 1 Feb 2021) 
198

199

200

201

202

203

204

205

206

207

208

209

210

211

212

213

214

215

216

217

218

219

220

221

222

223

224

225

226

227

228

229

230

231

232

233

234

235

236

Using the official Mexican data, we have chosen to analyze only the correlation between demographic patterns i.e. population size and density with the number of contagious and victims in the two pandemics (Pequeno et al., 2020).

The official data of CENAPRECE (http:/www.cenaprece.salud.gob.mx/) related to ccH1N1 and $\mathrm{dH} 1 \mathrm{~N} 1$ were used in this analysis while the geoportal of Mexico's government (https://coronavirus.gob.mx/datos/) was adopted to find the data of ccCOVID-19 and deaths dCOVID-19 related to the pandemic.

The results are presented as tables, graphs and thematic maps. The thematic maps were obtained using ArcMap 10.5 (ESRI, USA); two attributes have been drawn (population size counts of confirmed cases or counts of deaths) in each map. A special focus was directed to Federal District of CDMX.

A Spearman correlation was performed to assess the associations between the pandemics data and demographic patterns. Correlations with $p$ values $<0.05$ were considered significant. The Spearman coefficient values range between -1 to 1 and indicate negative or positive correlation, the values close to zero indicate poor or no correlation between the variables.

The nonparametric method locally weighted linear regression (LOESS), developed thought the programming language Python, have been used according to Austin and Steyerberg (2014) for the estimation of relationships between the demographic and pandemics indicators; the results were presented through XY graphs.

\section{RESULTS}

\section{The H1N1 influenza pandemic}

The first ccH1N1 were recorded in the small rural town of La Gloria, Veracruz (central part of Mexico) at the end of March, 2009. The national ccH1N1 and dH1N1 registered by CENAPRECE (http://www.cenaprece.salud.gob.mx/) during the sanitary emergency were 72366 and 1244 respectively.

The thematic maps (Figs. 1a and 1b) describe the spatial distribution of ccH1N1 and dH1N1 in Mexico and their association with population density. The CDMX was the most affected area by the "Swine flu" pandemic with $8502 \mathrm{ccH} 1 \mathrm{~N} 1$ and $152 \mathrm{dH} 1 \mathrm{~N} 1$. Other four FEs passed the threshold of $4000 \mathrm{ccH1N} 1$ i.e. State of Mexico (4682 ccH1N1), San Luis Potosí (4446 ccH1N1), Nuevo León (4358 ccH1N1) and Jalisco (4333 ccN1N1). The ccH1N1 were less than a thousand people in six FEs i.e. Baja California Sur, Morelos, Quintana Roo, Sinaloa, Coahuila and Campeche. The ccH1N1 ranged between 1000 and 4000 in the rest of the FEs (Table 1).

The Spearman correlation at federal scale (Fig. 2a) indicated different results. The ccH1N1 and $\mathrm{dH} 1 \mathrm{~N} 1$ (in absolute terms) were positively correlated (high correlation) with the demographic patterns. The $\% \mathrm{ccH} 1 \mathrm{~N} 1$ showed a negative correlation with the population size (Spearman rho: -0.43, $p$ : 0.011). A $p$-value higher than the level of marginal significance (i.e. $p>0.05$ ) was found analyzing the correlation between the $\% \mathrm{ccH} 1 \mathrm{~N} 1$ and the population density, also the correlation between the $\% \mathrm{dH} 1 \mathrm{~N} 1$ and population density was not significant. It is 
237 probable than the federal scale was not suitable for describing the correlation between the

238

239

240

241

242

243

244

245

246

247

248

249

250

251

252

253

254

255

256

257

258

259

260

261

262

263

264

265

266

267

268

269

270

271

272

273

274

275

variables under investigation. The data at municipal scale is not available.

\section{The COVID-19 pandemic}

Mexican health authorities confirmed the first SARS-CoV-2 positive case in the country at the end of February 2020, a young man who was in CDMX, hospitalized at the National Institute of Respiratory Diseases (INER) that had previously travelled to Italy. Starting from March 2020 the ccCOVID-19 and consequently the victims have increased considerably, placing Mexico among the first places in the unpleasant ranking of countries most affected by COVID-19 pandemic.

The thematic maps (Figs. 3a and 3b) describe the spatial distribution of ccCOVID-19 and dCOVID-19 in Mexico and their association with population density, while the Figs. $4 \mathrm{a}$ and $4 \mathrm{~b}$ show a special focus on CDMX.

The official data of national government (https://coronavirus.gob.mx/datos/) indicated 75.0 million ccCOVID-19 and 1.6 million dCOVID-19 as of date (18 ${ }^{\text {th }}$ December, 2020). The CDMX, where 264330 infections were registered, is the national epicenter of the pandemic (Table 2). The more crowed districts of the capital such as Iztapalapa (37332 ccCOVID-192812 dCOVID-19), Gustavo A. Madero (31778 ccCOVID-19 - 2570 dCOVID-19) and Tlalpan (24598 ccCOVID-19 - 765 dCOVID-19) are the principal "red zones" of the country where the pressure on the health system is greatest.

Other FEs that have exceeded the threshold of 40000 ccCOVID-19 are mainly located in the north - central area of the country or in the Gulf of Mexico, i.e. State of Mexico (125628 ccCOVID-19 - 16800 dCOVID-19), Nuevo León (73900 ccCOVID-19 - 4810 dCOVID-19), Guanajuato (72849 ccCOVID-19 - 4563 dCOVID-19), Sonora (47195 ccCOVID-19 - 3700 dCOVID-19), Jalisco (46165 ccCOVID-19 - 5287 dCOVID-19), Puebla (42728 ccCOVID-19 5350 dCOVID-19), Veracruz de Ignacio de la Llave (41316 ccCOVID-19 - 6105 dCOVID-19) and Tabasco (40355 ccCOVID-19 - 3106 dCOVID-19).

The number of infections and deaths are also alarming in the State of Mexico; the cities of Ecatepec de Morelos (15684 ccCOVID-19 - 2247 dCOVID-19) and Nezahualcóyotl (12929 ccCOVID-19 - 1695 dCOVID-19) connected through a dense public transport network with CDMX are the most exposed areas to the COVID-19 health emergency. In Tlaxcala (9984 ccCOVID-19 - 1314 dCOVID-19), another State close to the capital, the majority of the ccCOVID-19 and dCOVID-19 were recorded in urban areas of Tlaxcala city (1857 ccCOVID-19 - 191 dCOVID-19). Approx. two thirds of the ccCOVID-19 in Guerrero (24723 ccCOVID-192581 dCOVID-19) were found in the Acapulco de Juárez (10781 ccCOVID-19 - 1218 dCOVID19 ) and in the neighboring city of Chilpancingo de los Bravo (4572 ccCOVID-19 - 276 dCOVID-19), the municipalities of the interior have, at least so far, clearly lower numbers of ccCOVID-19. Yucatan (25186 ccCOVID-19 - 2097 dCOVID-19) showed similar numbers to Guerrero, approx. half of the infections were registered in Merida (15221 ccCOVID-19 - 1175 dCOVID-19). Baja California Sur (15809 ccCOVID-19 - 709 dCOVID-19), Durango (23301 
276

277

278

279

280

281

282

283

284

285

286

287

288

289

290

291

292

293

294

295

296

297

298

299

300

301

302

303

304

305

306

307

308

309

310

311

312

313

314

315

ccCOVID-19 - 1390 dCOVID-19) and Colima (7534 ccCOVID-19 - 773 dCOVID-19) were among the FEs of Mexico with less incidence of the COVID-19 pandemic.

The disease fatality rate (quotient between dCOVID-19 and ccCOVID-19) at federal scale (Fig. 5a) ranged between $4.49 \%$ of Baja California Sur to $16.01 \%$ of Sinaloa.

The Spearman correlation, at federal scale (Fig. 2b), showed different results. On one hand the ccCOVID-19 and dCOVID-19 (in absolute terms) were positively correlated (high correlation) with the population size. On the other hand $p$-values higher than the level of marginal significance (i.e. $p>0.05$ ) were found analyzing the correlations between the $\%$ ccCOVID-19 and the demographic patterns; also the correlations between the $\% \mathrm{dH} 1 \mathrm{~N} 1$ and the demographic patterns were not significant. These results lead us to suppose that the federal scale do not allow to observe the correlation between the pandemics indicators and the two demographic patterns, therefore the next step was to choose a more detailed geographical scale, i.e. on a municipal basis.

The Spearman analysis, at municipal scale (Fig. 2c) (2455 municipalities), showed high correlation between the data. The ccCOVID-19 and dCOVID-19 (in absolute terms) were high positively correlated with the demographic patterns; also the \% ccCOVID-19 and \% dCOVID-19 showed moderate high correlations with demographic patterns.

The municipal scale resulted more suitable than the federal scale to describe the spread of COVID-19 pandemic. The $\mathrm{R}^{2}$ of LOESS (Fig. 6a) was equal to 0.76 indicating medium high correlation between ccCOVID-19 and municipal population, while the $\mathrm{R}^{2}$ of 0.91 indicated high correlation between dCOVID-19 and the municipal population (Fig. 6b). However, it is important to emphasize that correlation is not causation and it is not right to say that high population sizes caused more dCOVID-19 despite the analysis regression showed that the variables were related to each other's.

The urban areas, i.e. federal capitals and principal municipalities, were particularly affected by the COVID-19 pandemic; some example: in the city of La Paz, where approximately the $37.52 \%$ of the total Baja California Sur' population lives, the $50.22 \%$ of federal ccCOVID-19 were registered; Ciudad Juárez, the biggest city of Chihuahua with the $44.06 \%$ of federal population, showed the $53.81 \%$ of federal ccCOVID-19; also in the port city of Veracruz, one of the most important trading centers in the Gulf of Mexico where the $7.34 \%$ of federal population lives, the federal ccCOVID-19 were the $21.56 \%$.

The discrepancy between the $\%$ of the federal population and the $\%$ of federal ccCOVID-19 was visible in most cases throughout all of Mexico (Table 3): Aguascalientes (Aguascalientes), Mexicali (Baja California), San Francisco de Campeche (Campeche), Tuxtla Gutiérrez (Chiapas), Colima (Colima), Victoria de Durango (Durango), León (Guanajuato), Acapulco de Juárez and Chilpancingo de los Bravo (Guerrero), Pachuca de Soto (Hidalgo), Guadalajara (Jalisco), Morelia (Michoacán), Cuernavaca (Morelos), Tepic (Nayarit), Monterrey (Nuevo León), Oaxaca de Juárez (Oaxaca), Puebla de Zaragoza (Puebla), Santiago de Querétaro (Querétaro), Cancun - Benito Juárez and Chetumal - Othón P. Blanco (Quintana Roo), San Luis Potosí (San Luis Potosí), Culiacán Rosales (Sinaloa), Hermosillo (Sonora), Ecatepec de Morelos, 
316 Nezahualcóyotl and Toluca de Lerdo (State of Mexico), Villahermosa - Centro (Tabasco),

317 Ciudad Victoria (Tamaulipas), Tlaxcala (Tlaxcala), Merida (Yucatan), Zacatecas (Zacatecas).

318 The discrepancy between the previously indicated values should not exist under uniform

319 conditions, probably it could be traced back by the incidence of key factors such as population

320 size and density.

321 The disease fatality rate, at municipal basis ranged until approx. 20.00\% (Baja California);

322 values of approx. $14.00 \%$ where found in many cities of Mexico including Cuernavaca

323 (Morelos), Culiacan (Sinaloa), Ecatepec de Morelos and Nezahualcoyotl (State of Mexico),

324 Veracruz (Veracruz de Ignacio de la Llave). In CDMX the disease fatality rate (Fig. 5b) ranged

325 between $2.50 \%$ of Milpa Alta and approx. $7.50 \%$ of the Iztapalapa and Iztacalco.

326

327

\section{DISCUSSION}

328

329

330

331

332

333

334

335

336

337

338

339

340

341

342

343

344

345

346

347

348

349

350

351

352

353

354

\section{The pandemics in Mexico}

The COVID-19 pandemic is increasing worldwide, with the American continent as one of its epicenters and Mexico is among the ten worst countries in terms of infections and deaths.

The magnitude of COVID-19 pandemic is much higher than the "Swine flu" pandemic; nevertheless it is possible to identify common aspects and differences between the two health emergencies. As in 2009 the most populated FEs of Mexico are the "red spots of infection" and report the greatest number of confirmed cases and deaths.

The authorities have been trying to reduce the spread of the COVID-19 by mitigation activities and strategies such as social distancing, travel restrictions, closing schools, shutting down nonessential activities and quarantine (Méndez-Arriaga, 2020), as they had previously done during the 2009 health emergency (Chowell et al., 2008). The major trouble has been identifying the root and the new cluster of infection in the urban areas.

The SARS-CoV-2 is transmitted by human-to-human, symptomatic people are the most frequent source of contagious; the virus can also be spread by contaminated objects and aerosol inhalation (Helmy et al., 2020). The metropolitan areas, involving districts tightly linked through socio-economic relationships and permanent commuting of citizens, workers and tourists are more exposed to the pandemic outbreaks compared to rural areas (Hamidi, Sabouri \& Ewing, 2020). Several causes could explain the correlation, observed at municipal scale, between demographic factors and the COVID-19 spread. The urban areas or those with high population size and density imply that more people live in per unit of area increasing the direct and indirect contact among the citizens, workers and tourist (Macharia, Joseph \& Okiro, 2020). Chhikara et al. (2020) indicate that high population density increased the possibility of COVID-19 diffusion, the urban-rural segmentation reduced the spread of outbreaks between urban and rural areas.

Méndez-Arriaga (2020), investigated environmental climate patterns of COVID-19 spread in Mexico, showing that the highest national local transmission in CDMX and State of Mexico were not only the result of the environmental factors (temperature and regional climate) but also the demographic characteristics (population size and density). 
355

356

357

358

359

360

361

362

363

364

365

366

367

368

369

370

371

372

373

374

375

376

377

378

379

380

381

382

383

384

385

386

387

388

389

390

391

392

393

394

According to Chowell et al. (2011) the three H1N1 pandemic waves across Mexican FEs were driven by the most populated cities, the earlier onset occurred in the overcrowded FEs located in the central part of the country, as it is nowadays during the COVID-19 emergency; however, in their publication the authors indicated that incidence rates observed in large population centers was lowest if compared with rural zone. The rural zones, as well as the degraded peripheral areas, in most cases, have structural gaps i.e. small and poorly efficient hospitals, precarious sanitary conditions that could accelerate the spread of infectious diseases.

In regard to COVID-19 pandemic, several countries are facing a second wave of infections, however, Mexico has not been the case yet and this study does not cover that scenario.

\section{Sanitary emergencies in CDMX}

The CDMX is the national epicenter point of the actual outbreak; all its citizens, that live closely in a "reduced space", appear to have accelerated the virus spread through multiple contacts and interactions in packed subway trains, busy playgrounds and crowded residential buildings creating "red spots" of infections.

In particular, the districts of Iztapalapa and Gustavo A. Madero had the highest incidence of COVID-19 confirmed cases at national scale.

According to Zepeda-Lopez et al. (2010), also during the outbreak of the novel influenza A (H1N1)v virus in 2009, CDMX showed the higher number of ccH1N1 principally in the crowed districts of Iztapalapa and Gustavo A. Madero. According to Ponnambalam et al. (2012) and You, Wu \& Guo (2020) population density, size if population and urban land are key factors in the infectious diseases transmission and, consequently, the urban areas present a significant challenge for national public health.

The underground (metro), with approximately 4.5 million commuters every day (1.6 billion ridership per year), is the most crowded urban transportation system of CDMX. It brings people in close contact and facilitates the virus spread by human-to-human transmission. During the daily massive movements, the passengers, sharing the same elements (surfaces, objects) and air, promoted a significant interchange of human or environmental microbiota causing the wider spread of pathogens (Vargas-Robles et al., 2020). The terminal stations such as Indios Verdes in the delegation of Gustavo A. Madero (north of CDMX) and Pantitlan in Venustiano Carranza (east of CDMX) that connect the inner city to suburban areas of Ecatepec de Morelos and Nezahualcóyotl (State of Mexico) were considered among the main "red spots" of COVID-19 contagious in CDMX by national government.

In contrast to the policies implemented by most of countries worldwide, Mexico in March 2020 preferred not to apply restrictions for air travel keeping the Benito Juárez International Airport of CDMX opened, that is the nation's main gateway with approximately 50 million commuters every year. Foreign tourists or Mexican citizens returning may have been vectors of the virus.

Massive religious events, such as the representation of the crucifixion of Jesus in Iztapalapa (Iztapalapa Passion Play 2009), which was held few days before the identification of the virus A 
395 (H1N1) pdm09 and was attended by more than 2 million people, were indeed dangerous events 396 for the spread of the virus at that time. According to Zepeda-Lopez et al. (2010) the congregation 397 of people in the Iztapalapa Passion Play has contributed to the roll out of the virus A (H1N1) 398 pdm09 during the initial outbreak phase throughout CDMX and beyond. Even more, while music

399

400

401

402

403

404

405

406

407

408

409

410

411

412

413

414

415

416

417

418

419

420

421

422

423

424

425

426

427

428

429

430

431

432

433

434 events such as Estéreo Picnic, Lollapalooza Chile, Argentina y Brazil were reprogrammed for next year, the "Vive Latino", one of the most important Rock festivals in Latin America took place in the midst of COVID-19 pandemic, on $14^{\text {th }}$ and $15^{\text {th }}$ March at the Foro Sol Stadium in CDMX, gathering more of 40000 people. The government and festival organization, instead of suspending the musical show and postpone it on another occasion, have chosen to take health preventive measures installing eight medical tents, filters with infrared thermometers at the entrances, and a team of 92 paramedics, 10 doctors and 8 ambulances (https://www.salud.cdmx.gob.mx/).

The government of CDMX identified seven market places including "Central de Abasto" in Iztapalapa and "La Merced" in Cuauhtémoc as significant sources of infection. They recommended the citizens to avoid buying groceries in those places. In particular, the "Central de Abasto", that supplies the capital and the center of the country and receives perishable food from all of Mexico, is an agglomeration point in the city representing high risk infection. The entry at this place was prohibited to pregnant women, children and older adults and the use of facemask mandatory.

Misleading statements by government representatives and the lack of official restrictions i.e. other than the closure of schools and suspension of classes in all academic levels, had left many of the preventative measures to citizen's "good judgment", since self isolation was voluntary, in the poorest areas of the CDMX such as Iztapalapa where several thousands of informal workers that have no other means of subsistence, and live on a "day to day" basis, need to work daily to meet basic family needs putting their health and their families at risk. Hence the decision to close the capital's "Zócalo" starting from the last week of March with almost 270 metal fences that protected the place in order to avoid crowds, potential meetings or social outings.

Public and private universities in CDMX have taken mitigation measures against the strain of COVID-19, suspending face-to-face activities and starting online programs. Chowell et al. (2011) analyzing the epidemiological patterns of "Swine flu" pandemic highlighted the importance of school closure and other restriction measures to mitigate the impact of "Swine flu" pandemic and future sanitary emergencies in urban and rural areas.

High densely populated cities within the same country have shown a grater out brake of COVID-19 than less densely populated cities (Tira, 2020). However, it is important to mention the limitations of the observations presented here since the analysis were made using phew parameters i.e. population, $\mathrm{km}^{2}$, population density, ccCOVID-19 and dCOVID-19; several other studies have shown the need to focus also on weather differences among regions (Rashed et al., 2020), seasonality (Smit et al., 2020; Carlson et al., 2020) and social parameters such as income (Bonacini, Gallo \& Scicchitano, 2020). 
435

436

437

438

439

440

441

442

443

444

445

446

447

448

449

450

451

452

453

454

455

456

457

458

459

460

461

462

463

464

465

466

467

468

469

470

471

\section{CONCLUSIONS}

The geographical scale results a key factor to accurately describe the spread of viral diseases in Mexico; an adequate geographical scale of reference is crucial for designing more efficient control or mitigation measures in such a heterogeneous and socially complex population during pandemic emergencies. The municipality scale that used of 2455 data against the 32 data of federal scale decreasing the uncertainty of the analysis and confirmed the correlation between demographic parameters and pandemic indicators; in our research a detailed geographic scale has produced better correlates with available data and highlighted the areas most exposed to the health emergency such us the delegation of Iztapalapa and Gustavo A. Madero in CDMX.

\section{ACKNOWLEDGEMENTS}

The authors thank one anonymous reviewer for helpful comments on a previous version of the manuscript.

\section{ADDITIONAL INFORMATION AND DECLARATIONS} Funding

The authors received no funding for this work.

\section{Competing Interests}

The authors declare that they have no competing interests.

\section{Author Contributions}

- Yohanna Sarria-Guzmán conceived and designed the experiments, performed the experiments, prepared figures and/or tables, authored or reviewed drafts of the paper, and approved the final draft.

- Jaime E. Bernal performed the experiments, authored or reviewed drafts of the paper, and approved the final draft.

- Michele De Biase analyzed the data, authored or reviewed drafts of the paper, and approved the final draft.

- Ligia C. Muñoz-Arenas analyzed the data, authored or reviewed drafts of the paper, and approved the final draft.

- Francisco Erik González-Jiménez prepared tables, authored or reviewed drafts of the paper, and approved the final draft.

- Clemente Mosso-González analyzed the data, authored or reviewed drafts of the paper, and approved the final draft.

- Arit S. De León-Lorenzana, authored or reviewed drafts of the paper, and approved the final draft. 
472

473

474

475

476

477

478

479

480

481

482

483

484

485

486

487

488

489

490

491

492

493

494

495

496

497

498

499

500

501

502

503

504

505

506

507

508

509

510

- Carmine Fusaro conceived and designed the project, performed the experiments, analyzed the data, prepared figures and/or tables, authored or reviewed drafts of the paper, and approved the final draft.

\section{REFERENCES}

Alqahtani JS, Oyelade T, Aldhahir AM, Alghamdi SM, Almehmadi M, Alqahtani AS, Quaderi S, Mandal S, Hurst JR. 2020. Prevalence, Severity and Mortality associated with COPD and Smoking in patients with COVID-19: A Rapid Systematic Review and MetaAnalysis. PloS one, 15(5), e0233147. https://doi.org/10.1371/journal.pone.0233147

Austin PC, Steyerberg EW. 2014. Graphical assessment of internal and external calibration of logistic regression models by using loess smoothers. Statistics in medicine, 33(3), 517-535. https://doi.org/10.1002/sim.5941

Barreto ML, Teixeira MG, Bastos FI, Ximenes RA, Barata RB, Rodrigues LC. 2011. Successes and failures in the control of infectious diseases in Brazil: social and environmental context, policies, interventions, and research needs. Lancet, 377(9780), 1877-1889. https://doi.org/10.1016/S0140-6736(11)60202-X

Bonacini L, Gallo G, Scicchitano S. 2020. Working from home and income inequality: risks of a 'new normal' with COVID-19. Journal of population economics, 1-58. Advance online publication. https://doi.org/10.1007/s00148-020-00800-7

Carlson CJ, Gomez ACR, Bansal S, Ryan SJ. 2020. Misconceptions about weather and seasonality must not misguide COVID-19 response. Nature communications, 11(1), 4312. https://doi.org/10.1038/s41467-020-18150-Z

Centers for Disease Control and Prevention-CDC. 2020. (accessed 26 $6^{\text {th }}$ August, 2020). https://www.cdc.gov

Centro Nacional de Programas Preventivos y Control de Enfermedades - CENAPRECE. 2020. (accessed $26^{\text {th }}$ August, 2020). http://www.cenaprece.salud.gob.mx/

Chhikara BS, Rathi B, Singh J \& Poonam FNU. 2020. Corona virus SARS-CoV-2 disease COVID-19: Infection, prevention and clinical advances of the prospective chemical drug therapeutics. Chemical Biology Letters, 7(1), 63-72.

Chowell G, Bettencourt LM, Johnson N, Alonso WJ, Viboud C. 2008. The 1918-1919 influenza pandemic in England and Wales: spatial patterns in transmissibility and mortality impact. Proceedings. Biological sciences, 275(1634), 501-509. https://doi.org/10.1098/rspb.2007.1477

Chowell G, Echevarría-Zuno S, Viboud C, Simonsen L, Tamerius J, Miller MA, BorjaAburto VH. 2011. Characterizing the epidemiology of the 2009 influenza A/H1N1 pandemic in Mexico. PLoS medicine, 8(5), e1000436. https://doi.org/10.1371/journal.pmed.1000436

Comisión Nacional para el Conocimiento y Uso de la Biodiversidad-CONABIO. 2020. (accessed 26 ${ }^{\text {th }}$ August, 2020). http://www.conabio.gob.mx/informacion/gis/ 
511

512

513

514

515

516

517

518

519

520

521

522

523

524

525

526

527

528

529

530

531

532

533

534

535

536

537

538

539

540

541

542

543

544

545

546

547

548

549

550

COVID-19 Tablero México-CONACYT-CentroGeo-GeoInt- DataLab. 2020. $\left(\right.$ accessed $16^{\text {th }}$
December, 2020). https://coronavirus.gob.mx/datos/

Crum-Cianflone NF, Blair PJ, Faix D, Arnold J, Echols S, Sherman SS, Tueller JE, Warkentien T, Sanguineti G, Bavaro M, Hale BR. 2009. Clinical and epidemiologic characteristics of an outbreak of novel H1N1 (swine origin) influenza A virus among United States military beneficiaries. Clinical infectious diseases: an official publication of the Infectious Diseases Society of America, 49(12), 1801-1810. https://doi.org/10.1086/648508 Dalziel BD, Kissler S, Gog JR, Viboud C, Bjørnstad ON, Metcalf CJE, Grenfell BT. 2018. Urbanization and humidity shape the intensity of influenza epidemics in U.S. cities. Science (New York, N.Y.), 362(6410), 75-79. https://doi.org/10.1126/science.aat6030

Fang LQ, Wang LP, de Vlas SJ, Liang S, Tong SL, Li YL, Li YP, Qian Q, Yang H, Zhou MG, Wang XF, Richardus JH, Ma JQ, Cao WC. 2012. Distribution and risk factors of 2009 pandemic influenza A (H1N1) in mainland China. American journal of epidemiology, 175(9), 890-897. https://doi.org/10.1093/aje/kwr411

Fraser C, Donnelly CA, Cauchemez S, Hanage WP, Van Kerkhove MD, Hollingsworth TD, Griffin J, Baggaley RF, Jenkins HE, Lyons EJ, Jombart T, Hinsley WR, Grassly NC, Balloux F, Ghani AC, Ferguson NM, Rambaut A, Pybus OG, Lopez-Gatell H, Alpuche-Aranda CM, Chapela IB, Zavala EP, Guevara DM, Checchi F, Garcia E, Hugonnet S, Roth C; WHO Rapid Pandemic Assessment Collaboration. 2009.

Pandemic potential of a strain of influenza A (H1N1): early findings. Science (New York, N.Y.), 324(5934), 1557-1561. https://doi.org/10.1126/science.1176062

Gerli AG, Centanni S, Miozzo MR, Virchow JC, Sotgiu G, Canonica GW, Soriano JB. 2020. COVID-19 mortality rates in the European Union, Switzerland, and the UK: effect of timeliness, lockdown rigidity, and population density. Minerva medica, 111(4), 308-314. https://doi.org/10.23736/S0026-4806.20.06702-6

Gobierno de México - Secretaría de Salud. (accessed $16^{\text {th }}$ December, 2020). https://www.salud.cdmx.gob.mx/, 2020

Hamidi S, Sabouri S \& Ewing R. 2020. Does density aggravate the COVID-19 pandemic?. Journal of the American Planning Association, 86(4), 495-509. https://doi.org/10.1080/01944363.2020.1777891

Helmy YA, Fawzy M, Elaswad A, Sobieh A, Kenney SP, Shehata AA. 2020. The COVID-19 Pandemic: A Comprehensive Review of Taxonomy, Genetics, Epidemiology, Diagnosis, Treatment, and Control. Journal of clinical medicine, 9(4), 1225. https://doi.org/10.3390/jcm9041225

Instituto Nacional de Estadística, Geografía e Informática-INEGI. 2020. (accessed $26^{\text {th }}$ August, 2020). https://www.inegi.org.mx/app/areasgeograficas/

Johns Hopkins University \& Medicine. 2020. (accessed $18^{\text {th }}$ December, 2020). https://coronavirus.jhu.edu/map.html

Jordan RE, Adab P, Cheng KK. 2020. Covid-19: risk factors for severe disease and death. BMJ (Clinical research ed.), 368, m1198. https://doi.org/10.1136/bmj.m1198 
551 Kain T, Fowler R. 2019. Preparing intensive care for the next pandemic influenza. Critical care

552

553

554

555

556

557

558

559

560

561

562

563

564

565

566

567

568

569

570

571

572

573

574

575

576

577

578

579

580

581

582

583

584

585

586

587

588 (London, England), 23(1), 337. https://doi.org/10.1186/s13054-019-2616-1

Lim BH, Mahmood TA. 2011. Influenza A H1N1 2009 (Swine Flu) and Pregnancy. Journal of obstetrics and gynaecology of India, 61(4), 386-393. https://doi.org/10.1007/s13224-0110055-2

Ma Y, Xu QN, Wang FL, Ma XM, Wang XY, Zhang XG, Zhang ZF. 2020. Characteristics of asymptomatic patients with SARS-CoV-2 infection in Jinan, China. Microbes and infection, 22(4-5), 212-217. https://doi.org/10.1016/j.micinf.2020.04.011

Macharia PM, Joseph NK, Okiro EA. 2020. A vulnerability index for COVID-19: spatial analysis at the subnational level in Kenya. BMJ global health, 5(8), e003014. https://doi.org/10.1136/bmjgh-2020-003014

Mehta P, McAuley DF, Brown M, Sanchez E, Tattersall RS, Manson JJ; HLH Across Speciality Collaboration, UK. 2020. COVID-19: consider cytokine storm syndromes and immunosuppression. Lancet (London, England), 395(10229), 1033-1034. https://doi.org/10.1016/S0140-6736(20)30628-0

Méndez-Arriaga F. 2020. The temperature and regional climate effects on communitarian COVID-19 contagion in Mexico throughout phase 1. The Science of the total environment, 735, 139560. https://doi.org/10.1016/j.scitotenv.2020.139560

Meng Y, Lu W, Guo E, Liu J, Yang B, Wu P, Lin S, Peng T, Fu Y, Li F, Wang Z, Li Y, Xiao R, Liu C, Huang Y, Lu F, Wu X, You L, Ma D, Sun C, Wu P, Chen G. 2020. Cancer history is an independent risk factor for mortality in hospitalized COVID-19 patients: a propensity score-matched analysis. Journal of hematology \& oncology, 13(1), 75. https://doi.org/10.1186/s13045-020-00907-0

Meyerowitz EA, Richterman A, Gandhi RT, Sax PE. 2021. Transmission of SARS-CoV-2: A Review of Viral, Host, and Environmental Factors. Annals of internal medicine, 174(1), 6979. https://doi.org/10.7326/M20-5008

Nieman DC, Wentz LM. 2019. The compelling link between physical activity and the body's defense system. Journal of sport and health science, 8(3), 201-217. https://doi.org/10.1016/j.jshs.2018.09.009

Pequeno P, Mendel B, Rosa C, Bosholn M, Souza JL, Baccaro F, Barbosa R, Magnusson W. 2020. Air transportation, population density and temperature predict the spread of COVID-19 in Brazil. PeerJ, 8, e9322. https://doi.org/10.7717/peerj.9322

Petrova VN, Russell CA. 2018. The evolution of seasonal influenza viruses. Microbiology, 16(1), 47-60. https://doi.org/10.1038/nrmicro.2017.118

Ponnambalam L, Samavedham L, Lee HR, Ho CS. 2012. Understanding the socioeconomic heterogeneity in healthcare in US counties: the effect of population density, education and poverty on H1N1 pandemic mortality. Epidemiology and infection, 140(5), 803-813. https://doi.org/10.1017/S0950268811001464 
589

590

591

592

593

594

595

596

597

598

599

600

601

602

603

604

605

606

607

608

609

610

611

612

613

614

615

616

617

618

619

620

621

622

623

624

625

626

627

628

Poole L. 2020. Seasonal influences on the spread of SARS-CoV-2 (COVID19), causality, and forecastabililty (3-15-2020) (March 15, 2020). Available at http://dx.doi.org/10.2139/ssrn.3554746

Ramírez IJ, Lee J. 2020. COVID-19 Emergence and Social and Health Determinants in Colorado: A Rapid Spatial Analysis. International journal of environmental research and public health, 17(11), 3856. https://doi.org/10.3390/ijerph17113856

Rashed EA, Kodera S, Gomez-Tames J, Hirata A. 2020. Influence of Absolute Humidity, Temperature and Population Density on COVID-19 Spread and Decay Durations: MultiPrefecture Study in Japan. International journal of environmental research and public health, 17(15), 5354. https://doi.org/10.3390/ijerph17155354

Rodrigue JP, Luke T \& Osterholm M. 2020. Transportation and pandemics. The Geography of Transport Systems, Fifth edition, New York: Routledge, 456 pages. ISBN 978-0-367-364632.

Roncon L, Zuin M, Rigatelli G, Zuliani G. 2020. Diabetic patients with COVID-19 infection are at higher risk of ICU admission and poor short-term outcome. Journal of clinical virology, 127, 104354. https://doi.org/10.1016/j.jcv.2020.104354

Saunders-Hastings P, Crispo JAG, Sikora L, Krewski D. 2017. Effectiveness of personal protective measures in reducing pandemic influenza transmission: A systematic review and meta-analysis. Epidemics, 20, 1-20. https://doi.org/10.1016/j.epidem.2017.04.003

Simonnet A, Chetboun M, Poissy J, Raverdy V, Noulette J, Duhamel A, Labreuche J, Mathieu D, Pattou F, Jourdain M; LICORN and the Lille COVID-19 and Obesity study group. 2020. High Prevalence of Obesity in Severe Acute Respiratory Syndrome Coronavirus-2 (SARS-CoV-2) Requiring Invasive Mechanical Ventilation. Obesity (Silver Spring, Md.), 28(7), 1195-1199. https://doi.org/10.1002/oby.22831

Smit AJ, Fitchett JM, Engelbrecht FA, Scholes RJ, Dzhivhuho G, Sweijd NA. 2020. Winter Is Coming: A Southern Hemisphere Perspective of the Environmental Drivers of SARSCoV-2 and the Potential Seasonality of COVID-19. International journal of environmental research and public health, 17(16), 5634. https://doi.org/10.3390/ijerph17165634

Sohrabi C, Alsafi Z, O'Neill N, Khan M, Kerwan A, Al-Jabir A, Iosifidis C, Agha R. 2020. World Health Organization declares global emergency: A review of the 2019 novel coronavirus (COVID-19). International journal of surgery, 76, 71-76. https://doi.org/10.1016/j.ijsu.2020.02.034

Tira M. 2020. About the Sustainability of Urban Settlements. TeMA-Journal of Land Use, Mobility and Environment, 361-371.

Vargas-Robles D, Gonzalez-Cedillo C, Hernandez AM, Alcaraz LD, Peimbert M. 2020. Passenger-surface microbiome interactions in the subway of Mexico City. PloS one, 15(8), e0237272. https://doi.org/10.1371/journal.pone.0237272

Vazquez-Prokopec GM, Kitron U, Montgomery B, Horne P, Ritchie SA. 2010. Quantifying the spatial dimension of dengue virus epidemic spread within a tropical urban environment. PLoS neglected tropical diseases, 4(12), e920. https://doi.org/10.1371/journal.pntd.0000920 
629

630

631

632

633

634

635

636

637

638

639

640

641

642

643

644

645

646

647

648

649

650

651

652

653

654

655

656

657

658

659

660

661

Verity R, Okell LC, Dorigatti I, Winskill P, Whittaker C, Imai N, Cuomo-Dannenburg G, Thompson H, Walker PGT, Fu H, Dighe A, Griffin JT, Baguelin M, Bhatia S, Boonyasiri A, Cori A, Cucunubá Z, FitzJohn R, Gaythorpe K, Green W, Hamlet A, Hinsley W, Laydon D, Nedjati-Gilani G, Riley S, van Elsland S, Volz E, Wang H, Wang Y, Xi X, Donnelly CA, Ghani AC, Ferguson NM. 2020. Estimates of the severity of coronavirus disease 2019: a model-based analysis. The Lancet. Infectious diseases, 20(6), 669-677. https://doi.org/10.1016/S1473-3099(20)30243-7

Wang B, Li R, Lu Z, Huang Y. 2020. Does comorbidity increase the risk of patients with COVID-19: evidence from meta-analysis. Aging, 12(7), 6049-6057. https://doi.org/10.18632/aging.103000

Widders A, Broom A, Broom J. 2020. SARS-CoV-2: The viral shedding vs infectivity dilemma. Infection, disease \& health, 25(3), 210-215.

https://doi.org/10.1016/j.idh.2020.05.002

Williamson EJ, Walker AJ, Bhaskaran K, Bacon S, Bates C, Morton CE, Curtis HJ, Mehrkar A, Evans D, Inglesby P, Cockburn J, McDonald HI, MacKenna B, Tomlinson L, Douglas IJ, Rentsch CT, Mathur R, Wong AYS, Grieve R, Harrison D, Forbes H, Schultze A, Croker R, Parry J, Hester F, Harper S, Perera R, Evans SJW, Smeeth L, Goldacre B. 2020. Factors associated with COVID-19-related death using OpenSAFELY. Nature, 584(7821), 430-436. https://doi.org/10.1038/s41586-020-2521-4

Witkop CT, Duffy MR, Macias EA, Gibbons TF, Escobar JD, Burwell KN, Knight KK. 2010. Novel Influenza A (H1N1) outbreak at the U.S. Air Force Academy: epidemiology and viral shedding duration. American journal of preventive medicine, 38(2), 121-126. https://doi.org/10.1016/j.amepre.2009.10.005

World Health Organization-WHO. 2020. (accessed 26 ${ }^{\text {th }}$ August, 2020). https://www.who.int You H, Wu X, Guo X. 2020. Distribution of COVID-19 Morbidity Rate in Association with Social and Economic Factors in Wuhan, China: Implications for Urban Development. International journal of environmental research and public health, 17(10), 3417. https://doi.org/10.3390/ijerph17103417

Zepeda-Lopez HM, Perea-Araujo L, Miliar-García A, Dominguez-López A, XoconostleCázarez B, Lara-Padilla E, Ramírez Hernandez JA, Sevilla-Reyes E, Orozco ME, Ahued-Ortega A, Villaseñor-Ruiz I, Garcia-Cavazos RJ, Teran LM. 2010. Inside the outbreak of the 2009 influenza A (H1N1)v virus in Mexico. PloS one, 5(10), e13256. https://doi.org/10.1371/journal.pone.0013256 


\section{Table 1 (on next page)}

Distribution of H1N1 pandemic in Mexico - Federal scale.

Note. Pop. Size: Population size, hab.: inhabitants, Pop. Density: Population density, ccH1N1:

Federal H1N1 confirmed cases, dH1N1: Federal H1N1 deaths, C.I.: Confidence Interval, S.D.: Standard deviation. 
Table 1. Distribution of H1N1 pandemic in Mexico - Federal scale.

\begin{tabular}{|c|c|c|c|c|c|c|}
\hline FE & $\begin{array}{l}\text { Pop. Size } \\
\text { hab. (2010) }\end{array}$ & $\begin{array}{c}\text { Pop. Density } \\
\text { hab./km² (2010) }\end{array}$ & ccH1N1 & dH1N1 & \% ccH1N1 & $\%$ dH1N1 \\
\hline Aguascalientes & 1184996 & 211 & 1718 & 48 & 0.14 & 0.0041 \\
\hline Baja California & 3155070 & 44 & 2143 & 47 & 0.07 & 0.0015 \\
\hline $\begin{array}{c}\text { Baja California } \\
\text { Sur }\end{array}$ & 637026 & 9 & 863 & 12 & 0.14 & 0.0019 \\
\hline Campeche & 822441 & 14 & 219 & 2 & 0.03 & 0.0002 \\
\hline CDMX & 8851080 & 5920 & 8502 & 152 & 0.10 & 0.0017 \\
\hline Chiapas & 4796580 & 65 & 3711 & 40 & 0.08 & 0.0008 \\
\hline Chihuahua & 3406465 & 14 & 1138 & 44 & 0.03 & 0.0013 \\
\hline Coahuila & 2748391 & 18 & 447 & 18 & 0.02 & 0.0007 \\
\hline Colima & 650555 & 116 & 1207 & 1 & 0.19 & 0.0002 \\
\hline Durango & 1632934 & 13 & 1298 & 18 & 0.08 & 0.0011 \\
\hline Guanajuato & 5486372 & 179 & 1501 & 52 & 0.03 & 0.0009 \\
\hline Guerrero & 3388768 & 53 & 2057 & 13 & 0.06 & 0.0004 \\
\hline Hidalgo & 2665018 & 128 & 2283 & 44 & 0.09 & 0.0017 \\
\hline Jalisco & 7350682 & 94 & 4333 & 75 & 0.06 & 0.0010 \\
\hline Michoacán & 4351037 & 74 & 2936 & 37 & 0.07 & 0.0009 \\
\hline Morelos & 1777227 & 364 & 785 & 22 & 0.04 & 0.0012 \\
\hline Nayarit & 1084979 & 39 & 1675 & 11 & 0.15 & 0.0010 \\
\hline Nuevo León & 4653458 & 73 & 4358 & 76 & 0.09 & 0.0016 \\
\hline Оахаса & 3801962 & 41 & 2284 & 60 & 0.06 & 0.0016 \\
\hline Puebla & 5779829 & 168 & 1773 & 54 & 0.03 & 0.0009 \\
\hline Querétaro & 1827937 & 156 & 1936 & 37 & 0.11 & 0.0020 \\
\hline Quintana Roo & 1325578 & 30 & 728 & 3 & 0.05 & 0.0002 \\
\hline San Luis Potosí & 2585518 & 42 & 4446 & 63 & 0.17 & 0.0024 \\
\hline
\end{tabular}




\begin{tabular}{|c|c|c|c|c|c|c|}
\hline Sinaloa & 2767761 & 48 & 643 & 15 & 0.02 & 0.0005 \\
\hline Sonora & 2662480 & 15 & 2401 & 23 & 0.09 & 0.0009 \\
\hline State of Mexico & 15175862 & 679 & 4682 & 140 & 0.03 & 0.0009 \\
\hline Tabasco & 2238603 & 91 & 1212 & 4 & 0.05 & 0.0002 \\
\hline Tamaulipas & 3268554 & 41 & 2395 & 22 & 0.07 & 0.0007 \\
\hline Tlaxcala & 1169936 & 291 & 1593 & 15 & 0.14 & 0.0013 \\
\hline $\begin{array}{l}\text { Veracruz de } \\
\text { Ignacio de la } \\
\text { Llave }\end{array}$ & 7643194 & 106 & 2454 & 27 & 0.03 & 0.0004 \\
\hline Yucatan & 1955577 & 49 & 3636 & 24 & 0.19 & 0.0012 \\
\hline Zacatecas & 1490668 & 20 & 1009 & 45 & 0.07 & 0.0030 \\
\hline 95\% C.I. & & & & & 0.02 & 0.0003 \\
\hline S.D. & & & & & 0.05 & 0.0008 \\
\hline
\end{tabular}

Note. Pop. Size: Population size, hab.: inhabitants, Pop. Density: Population density, ccH1N1: Federal H1N1 confirmed cases, dH1N1: Federal H1N1 deaths, C.I.: Confidence Interval, S.D.: Standard deviation. 
Figure 1

Thematic maps: Spatial distribution H1N1 pandemic in Mexico - population size.

(a) Federal H1N1 influenza confirmed cases - population size. ccH1N1: Federal H1N1 influenza confirmed cases (red circle), hab.: Federal population. (b) Federal H1N1 deaths population size. dH1N1: Federal H1N1 deaths (purple circle), hab.: Federal population. 


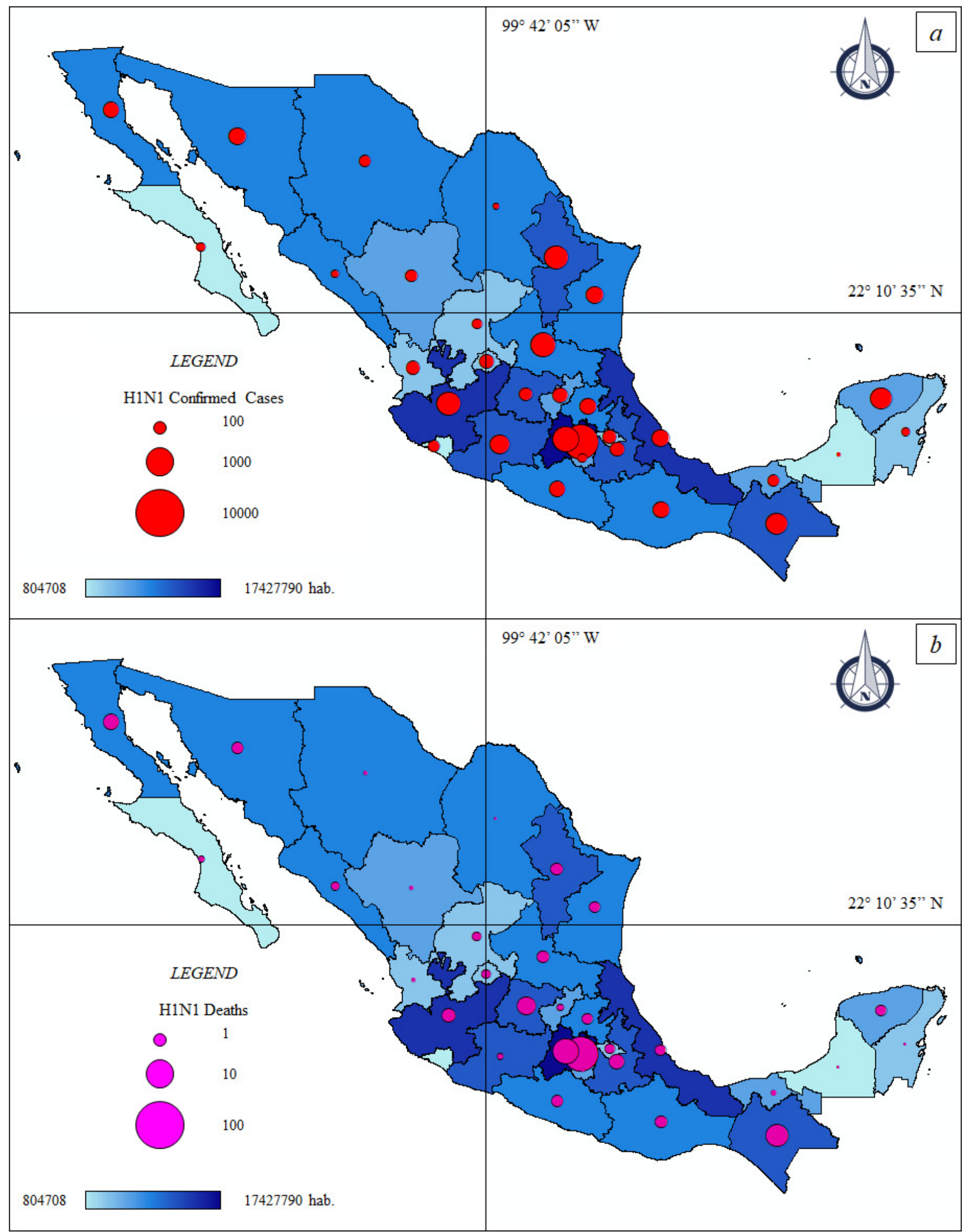




\section{Figure 2}

Spearman correlations between analyzed variables.

(a) Spearman correlation at federal scale - H1N1 pandemic 2009. hab.: Federal population, ccH1N1: Federal H1N1 influenza confirmed cases, dH1N1: Federal H1N1 deaths. (b) Spearman correlation at federal scale - COVID-19 pandemic. hab.: Federal population, ccCOVID-19: Federal COVID-19 confirmed cases, dCOVID-19: Federal COVID-19 deaths. (c) Spearman correlation at municipal scale - COVID-19 pandemic. hab.: Municipal population, ccCOVID-19: Municipal COVID-19 confirmed cases, dCOVID-19: Municipal COVID-19 deaths. Correlations with a $p$ value $<0.01$ was considered significant. N.S.: not significant value, $p$ value $>0.01$.

\section{Correlation scale}

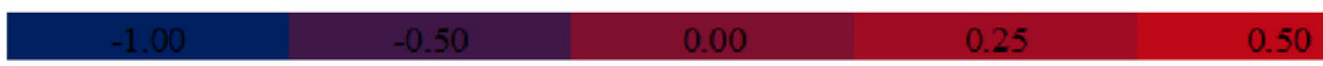

\section{N.S.}

a)

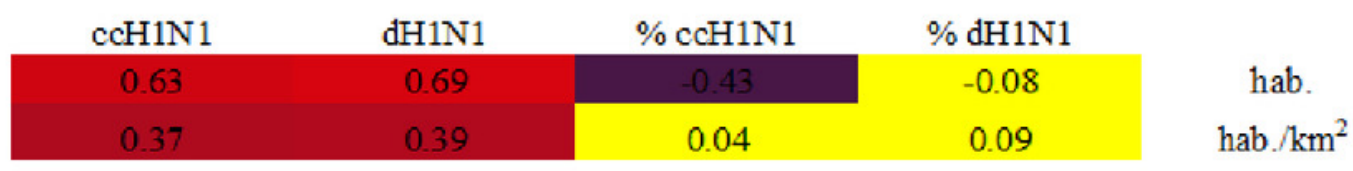

b)

\begin{tabular}{|cc|ccc|c}
\hline ccCOVID-19 & dCOVID-19 & \% coCOVID-19 & \% dCOVID-19 & \\
\hline 0.77 & 0.83 & -0.29 & -0.20 & hab. \\
0.37 & 0.39 & -0.22 & -0.15 & $\mathrm{hab} . \mathrm{km}^{2}$
\end{tabular}

c)

\begin{tabular}{ccccc} 
ccCovID-19 & dCOVID-19 & \% coCOVID-19 & \% dCOVID-19 & \\
\hline 0.85 & 0.81 & 0.44 & 0.51 & hab. \\
0.44 & 0.48 & 0.24 & 0.33 & hab. $/ \mathrm{km}^{2}$
\end{tabular}


Table 2 (on next page)

Distribution of COVID-19 pandemic in Mexico - Federal scale.

Note. Pop. Size: Population size, hab.: inhabitants, Pop. Density: Population density, ccCOVID-19: Federal COVID-19 confirmed cases, dCOVID-19: Federal COVID-19 deaths, C.I.: Confidence Interval, S.D.: Standard deviation. 
Table 2. Distribution of COVID-19 pandemic in Mexico - Federal scale.

\begin{tabular}{|c|c|c|c|c|c|c|}
\hline $\mathrm{FE}$ & $\begin{array}{l}\text { Pop. Size } \\
\text { hab. (2020) }\end{array}$ & $\begin{array}{c}\text { Density Pop. } \\
\text { hab./km² (2020) }\end{array}$ & ccCOVID-19 & dCOVID-19 & \% ccCOVID-19 & \% dCOVID-19 \\
\hline Aguascalientes & 1434635 & 255 & 15683 & 1218 & 1.09 & 0.08 \\
\hline Baja California & 3634868 & 51 & 29942 & 4783 & 0.82 & 0.13 \\
\hline $\begin{array}{c}\text { Baja California } \\
\text { Sur }\end{array}$ & 804708 & 11 & 15809 & 709 & 1.96 & 0.09 \\
\hline Campeche & 1000617 & 17 & 6993 & 946 & 0.70 & 0.09 \\
\hline CDMX & 9018645 & 6033 & 264330 & 14733 & 2.93 & 0.16 \\
\hline Chiapas & 5730367 & 78 & 7963 & 1177 & 0.14 & 0.02 \\
\hline Chihuahua & 3801487 & 15 & 33669 & 4086 & 0.89 & 0.11 \\
\hline Coahuila & 3218720 & 21 & 45280 & 3755 & 1.41 & 0.12 \\
\hline Colima & 785153 & 140 & 7534 & 773 & 0.96 & 0.10 \\
\hline Durango & 1868996 & 15 & 23301 & 1390 & 1.25 & 0.07 \\
\hline Guanajuato & 6228175 & 203 & 72849 & 4563 & 1.17 & 0.07 \\
\hline Guerrero & 3657048 & 58 & 24723 & 2581 & 0.68 & 0.07 \\
\hline Hidalgo & 3086414 & 148 & 21396 & 2988 & 0.69 & 0.10 \\
\hline Jalisco & 8409693 & 107 & 46165 & 5287 & 0.55 & 0.06 \\
\hline Michoacán & 4825401 & 82 & 30378 & 2489 & 0.63 & 0.05 \\
\hline Morelos & 2044058 & 419 & 8642 & 1356 & 0.42 & 0.07 \\
\hline Nayarit & 1288571 & 46 & 7518 & 1000 & 0.58 & 0.08 \\
\hline Nuevo León & 5610153 & 87 & 73900 & 4810 & 1.32 & 0.09 \\
\hline Оахаса & 4143593 & 44 & 26011 & 2009 & 0.63 & 0.05 \\
\hline Puebla & 6604451 & 193 & 42728 & 5350 & 0.65 & 0.08 \\
\hline Querétaro & 2279637 & 195 & 27036 & 1641 & 1.19 & 0.07 \\
\hline Quintana Roo & 1723259 & 39 & 15057 & 1978 & 0.87 & 0.11 \\
\hline San Luis Potosí & 2866142 & 47 & 37412 & 2787 & 1.31 & 0.10 \\
\hline Sinaloa & 3156674 & 54 & 25447 & 4093 & 0.81 & 0.13 \\
\hline
\end{tabular}




\begin{tabular}{|c|c|c|c|c|c|c|}
\hline Sonora & 3074745 & 17 & 47195 & 3700 & 1.53 & 0.12 \\
\hline State of Mexico & 17427790 & 780 & 125628 & 16800 & 0.72 & 0.10 \\
\hline Tabasco & 2572287 & 104 & 40355 & 3106 & 1.57 & 0.12 \\
\hline Tamaulipas & 3650602 & 45 & 37343 & 3114 & 1.02 & 0.09 \\
\hline Tlaxcala & 1380011 & 344 & 9984 & 1314 & 0.72 & 0.10 \\
\hline $\begin{array}{l}\text { Veracruz de Ignacio de } \\
\text { la Llave }\end{array}$ & 8539862 & 119 & 41316 & 6105 & 0.48 & 0.07 \\
\hline Yucatan & 2259098 & 57 & 25186 & 2097 & 1.11 & 0.09 \\
\hline Zacatecas & 1666426 & 22 & 19201 & 1560 & 1.15 & 0.09 \\
\hline 95\% C.I. & & & & & 0.19 & 0.01 \\
\hline S.D. & & & & & 0.52 & 0.03 \\
\hline
\end{tabular}

Note. Pop. Size: Population size, hab.: inhabitants, Pop. Density: Population density, ccCOVID-19: Federal COVID-19 confirmed cases, dCOVID-19: Federal COVID-19 deaths, C.I.: Confidence Interval, S.D.: Standard deviation. 
Figure 3

Thematic maps: Spatial distribution COVID-19 pandemic in Mexico - population size.

(a) Federal COVID-19 confirmed cases - population size. ccCOVID-19: Federal COVID-19 confirmed cases (red circle), hab.: Federal population. (b) Federal COVID-19 deaths population size. dCOVID-19: Federal COVID-19 deaths (purple circle), hab.: Federal population. 


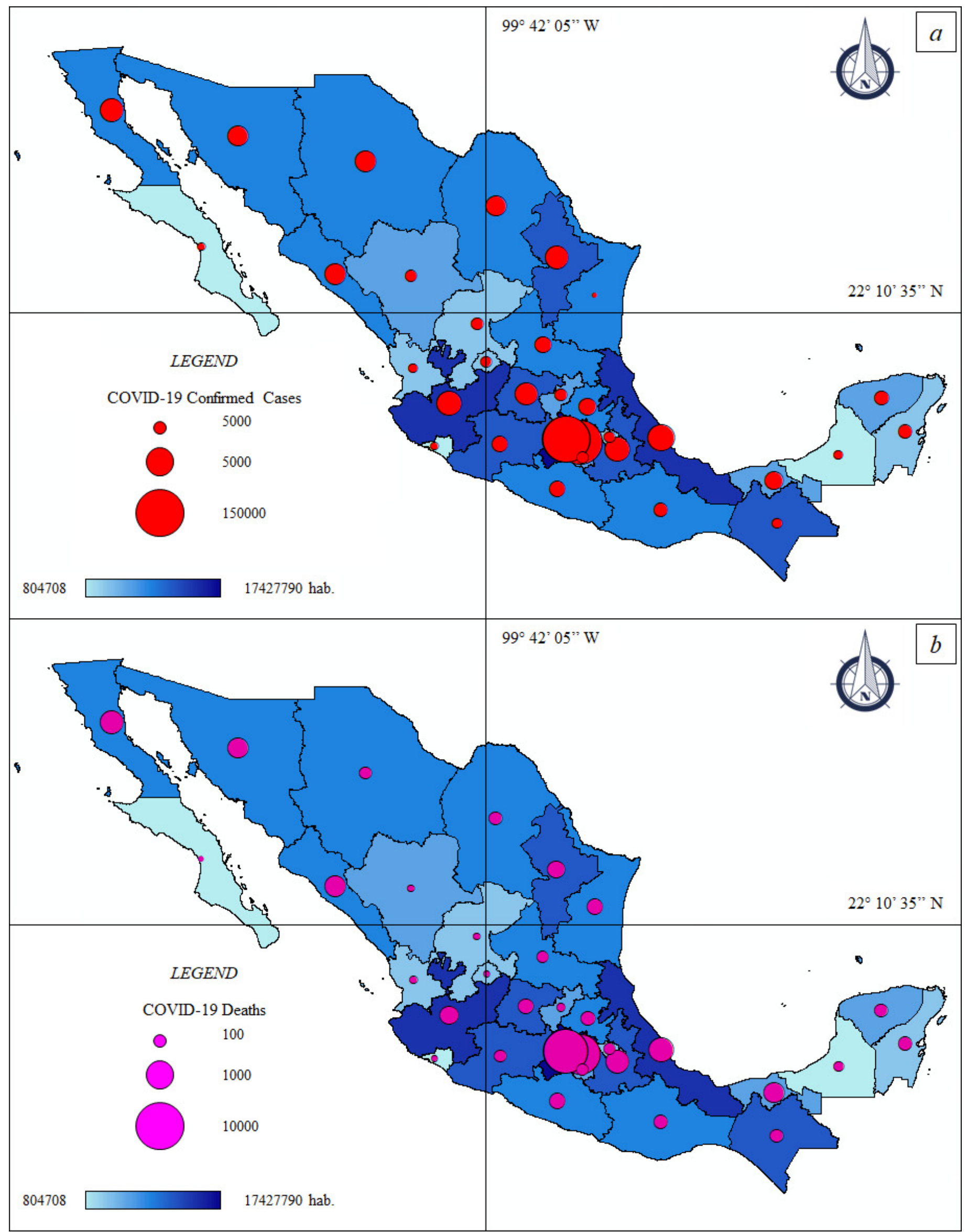




\section{Table 3(on next page)}

Distribution of COVID-19 in the principal municipalities or districts of Mexico - Municipal scale.

Note. C.I.: Confidence Interval, S.D.: Standard deviation. 
Table 3. Distribution of COVID-19 in the principal municipalities or districts of Mexico - Municipal scale.

\begin{tabular}{|c|c|c|c|c|c|c|c|}
\hline Federal Entities & $\begin{array}{c}\text { Major } \\
\text { municipalities or } \\
\text { districts }\end{array}$ & Population & $\begin{array}{c}\% \\
\text { Population } \\
\text { (Federal } \\
\text { Entities) }\end{array}$ & $\begin{array}{l}\text { Confirmed } \\
\text { COVID-19 } \\
\text { Cases }\end{array}$ & $\begin{array}{c}\% \\
\text { Confirmed } \\
\text { COVID-19 } \\
\text { Cases } \\
\text { (Federal } \\
\text { Entities) }\end{array}$ & $\begin{array}{l}\text { Confirmed } \\
\text { COVID-19 } \\
\text { Deaths }\end{array}$ & $\begin{array}{c}\% \\
\text { Confirmed } \\
\text { COVID-19 } \\
\text { Deaths } \\
\text { (Federal } \\
\text { Entities) }\end{array}$ \\
\hline \multirow[t]{2}{*}{ Aguascalientes } & & 1434635 & & 15683 & & 1218 & \\
\hline & Aguascalientes & 961977 & 67.05 & 12730 & 81.17 & 1077 & 88.42 \\
\hline \multirow[t]{3}{*}{ Baja California } & & 3634868 & & 29942 & & 4783 & \\
\hline & Mexicali & 1087478 & 29.92 & 13624 & 45.50 & 1996 & 41.73 \\
\hline & Tijuana & 1789531 & 49.23 & 9585 & 32.35 & 1973 & 41.25 \\
\hline \multirow[t]{2}{*}{$\begin{array}{l}\text { Baja California } \\
\text { Sur }\end{array}$} & & 804708 & & 15809 & & 709 & \\
\hline & La Paz & 301961 & 37.52 & 7939 & 50.22 & 343 & 48.38 \\
\hline \multirow[t]{2}{*}{ Campeche } & & 1000617 & & 6993 & & 946 & \\
\hline & $\begin{array}{l}\text { San Francisco de } \\
\text { Campeche }\end{array}$ & 317424 & 31.72 & 2909 & 41.60 & 370 & 39.11 \\
\hline \multirow[t]{2}{*}{ Chiapas } & & 5730367 & & 7963 & & 1177 & \\
\hline & Tuxtla Gutiérrez & 662591 & 11.56 & 2970 & 37.30 & 420 & 35.68 \\
\hline
\end{tabular}




\begin{tabular}{|c|c|c|c|c|c|c|c|}
\hline \multirow[t]{3}{*}{ Chihuahua } & & 3801487 & & 33669 & & 4086 & \\
\hline & Chihuahua & 949395 & 24.97 & 8194 & 24.34 & 824 & 20.17 \\
\hline & Ciudad Juárez & 1674973 & 44.06 & 18116 & 53.81 & 2366 & 57.91 \\
\hline \multirow[t]{2}{*}{$\begin{array}{l}\text { Coahuila de } \\
\text { Zaragoza }\end{array}$} & & 3218720 & & 45280 & & 3755 & \\
\hline & Saltillo & 869184 & 27.00 & 9269 & 20.47 & 950 & 25.30 \\
\hline \multirow[t]{2}{*}{ Colima } & & 785153 & & 7534 & & 773 & \\
\hline & Colima & 169188 & 21.55 & 2013 & 26.72 & 177 & 22.90 \\
\hline \multirow[t]{2}{*}{ Durango } & & 1868996 & & 23301 & & 1390 & \\
\hline & $\begin{array}{l}\text { Victoria de } \\
\text { Durango }\end{array}$ & 654876 & 35.04 & 12393 & 53.19 & 588 & 42.30 \\
\hline \multirow[t]{3}{*}{ Guanajuato } & & 6228175 & & 72849 & & 4563 & \\
\hline & Guanajuato & 198035 & 3.18 & 2620 & 3.60 & 132 & 2.89 \\
\hline & León & 1679610 & 26.97 & 24126 & 33.12 & 1814 & 39.75 \\
\hline \multirow[t]{3}{*}{ Guerrero } & & 3657048 & & 24723 & & 2581 & \\
\hline & $\begin{array}{l}\text { Acapulco de } \\
\text { Juárez }\end{array}$ & 840795 & 22.99 & 10781 & 43.61 & 1218 & 47.19 \\
\hline & $\begin{array}{l}\text { Chilpancingo de } \\
\text { los Bravo }\end{array}$ & 284330 & 7.77 & 4572 & 18.49 & 276 & 10.69 \\
\hline \multirow[t]{2}{*}{ Hidalgo } & & 3086414 & & 21396 & & 2988 & \\
\hline & Pachuca de Soto & 280312 & 9.08 & 4817 & 22.51 & 499 & 16.70 \\
\hline \multirow[t]{2}{*}{ Jalisco } & & 8409693 & & 46165 & & 5289 & \\
\hline & Guadalajara & 1503505 & 17.88 & 15837 & 34.31 & 1930 & 36.49 \\
\hline CDMX & & 9018645 & & 264330 & & 14733 & \\
\hline
\end{tabular}




\begin{tabular}{|c|c|c|c|c|c|c|c|}
\hline & Álvaro Obregón & 755537 & 8.38 & 27558 & 10.43 & 1191 & 8.08 \\
\hline & Azcapotzalco & 408441 & 4.53 & 14294 & 5.41 & 1058 & 7.18 \\
\hline & Benito Juárez & 433708 & 4.81 & 10129 & 3.83 & 499 & 3.39 \\
\hline & Coyoacán & 621952 & 6.90 & 17076 & 6.46 & 906 & 6.15 \\
\hline & $\begin{array}{l}\text { Cuajimalpa de } \\
\text { Morelos }\end{array}$ & 199809 & 2.22 & 6324 & 2.39 & 251 & 1.70 \\
\hline & Cuauhtémoc & 548606 & 6.08 & 15131 & 5.95 & 1050 & 7.13 \\
\hline & $\begin{array}{l}\text { Gustavo A. } \\
\text { Madero }\end{array}$ & 1176967 & 13.05 & 31778 & 12.02 & 2570 & 17.44 \\
\hline & Iztacalco & 393821 & 4.37 & 11598 & 4.39 & 895 & 6.07 \\
\hline & Iztapalapa & 1815551 & 20.13 & 37332 & 14.12 & 2812 & 19.09 \\
\hline & $\begin{array}{l}\text { La Magdalena } \\
\text { Contreras }\end{array}$ & 245147 & 2.72 & 9429 & 3.57 & 254 & 1.72 \\
\hline & Miguel Hidalgo & 379624 & 4.21 & 10511 & 3.98 & 574 & 3.90 \\
\hline & Milpa Alta & 139371 & 1.55 & 5803 & 2.23 & 148 & 1.00 \\
\hline & Tláhuac & 366586 & 4.06 & 13798 & 5.22 & 402 & 2.73 \\
\hline & Tlalpan & 682234 & 7.56 & 24598 & 9.31 & 765 & 5.19 \\
\hline & $\begin{array}{l}\text { Venustiano } \\
\text { Carranza }\end{array}$ & 433231 & 4.80 & 14231 & 5.38 & 843 & 5.72 \\
\hline & Xochimilco & 418060 & 4.64 & 14734 & 5.57 & 515 & 3.50 \\
\hline \multirow[t]{2}{*}{ Michoacán } & & 4825401 & & 30378 & & 2489 & \\
\hline & Morelia & 825585 & 17.11 & 7391 & 24.33 & 530 & 21.29 \\
\hline
\end{tabular}




\begin{tabular}{|c|c|c|c|c|c|c|c|}
\hline \multirow[t]{2}{*}{ Morelos } & \multicolumn{3}{|c|}{2044058} & \multirow{2}{*}{$\begin{array}{l}8642 \\
2424 \\
\end{array}$} & \multicolumn{3}{|c|}{1356} \\
\hline & Cuernavaca & 399426 & 19.54 & & 28.05 & 342 & 25.22 \\
\hline \multirow[t]{2}{*}{ Nayarit } & & 1288571 & & 7518 & & 1000 & \\
\hline & Tepic & 445889 & 34.60 & 3996 & 53.15 & 375 & 37.50 \\
\hline \multirow[t]{2}{*}{ Nuevo León } & & 5610153 & & 73900 & & 4810 & \\
\hline & Monterrey & 1124835 & 20.05 & 23194 & 31.39 & 1541 & 32.04 \\
\hline \multirow[t]{2}{*}{ Oaxaca } & & 4143593 & & 26011 & & 2009 & \\
\hline & Oaxaca de Juárez & 258636 & 6.24 & 7479 & 28.75 & 405 & 20.16 \\
\hline \multirow[t]{2}{*}{ Puebla } & & 6604451 & & 42728 & & 5350 & \\
\hline & $\begin{array}{l}\text { Puebla de } \\
\text { Zaragoza }\end{array}$ & 1698509 & 25.72 & 27301 & 63.89 & 2777 & 51.91 \\
\hline \multirow[t]{2}{*}{ Querétaro } & & 2279637 & & 27036 & & 1641 & \\
\hline & $\begin{array}{l}\text { Santiago de } \\
\text { Querétaro }\end{array}$ & 626495 & 27.48 & 20233 & 74.84 & 1117 & 68.07 \\
\hline \multirow[t]{4}{*}{ Quintana Roo } & & 1723259 & & 15057 & & 1978 & \\
\hline & $\begin{array}{l}\text { Cancun (Benito } \\
\text { Juárez) }\end{array}$ & 743626 & 43.15 & 6989 & 46.42 & 1250 & 63.20 \\
\hline & Chetumal & & & & & & \\
\hline & (Othón P. Blanco) & 265298 & 15.40 & 3975 & 26.40 & 226 & 11.43 \\
\hline San Luis Potosí & & 2866142 & & 37412 & & 2787 & \\
\hline
\end{tabular}




\begin{tabular}{|c|c|c|c|c|c|c|c|}
\hline & San Luis Potosí & 870578 & 30.37 & 21482 & 57.42 & 1501 & 53.86 \\
\hline \multirow[t]{2}{*}{ Sinaloa } & & 3156674 & & 25447 & & 4093 & \\
\hline & Culiacán Rosales & 962871 & 30.50 & 10668 & 41.92 & 1467 & 35.84 \\
\hline \multirow[t]{2}{*}{ Sonora } & & 3074745 & & 47195 & & 3700 & \\
\hline & Hermosillo & 946054 & 30.77 & 21830 & 46.25 & 1144 & 30.92 \\
\hline \multirow[t]{4}{*}{ State of Mexico } & & 17427790 & & 125628 & & 16800 & \\
\hline & $\begin{array}{l}\text { Ecatepec de } \\
\text { Morelos }\end{array}$ & 1707754 & 9.80 & 15684 & 12.48 & 2247 & 13.38 \\
\hline & Nezahualcóyotl & 1135786 & 6.52 & 12929 & 10.29 & 1695 & 10.09 \\
\hline & Toluca de Lerdo & 948950 & 5.45 & 9716 & 7.73 & 1101 & 6.55 \\
\hline \multirow[t]{2}{*}{ Tabasco } & & 2572287 & & 40355 & & 3106 & \\
\hline & $\begin{array}{l}\text { Villahermosa } \\
\text { (Centro) }\end{array}$ & 739611 & 28.75 & 20132 & 49.89 & 1356 & 43.66 \\
\hline \multirow[t]{3}{*}{ Tamaulipas } & & 3650602 & & 37343 & & 3114 & \\
\hline & Ciudad Victoria & 367051 & 10.05 & 5116 & 13.70 & 237 & 7.61 \\
\hline & Reynosa & 686670 & 18.81 & 5931 & 15.88 & 754 & 24.21 \\
\hline \multirow[t]{2}{*}{ Tlaxcala } & & 1380011 & & 9984 & & 1314 & \\
\hline & Tlaxcala & 103435 & 7.50 & 1857 & 18.60 & 191 & 14.54 \\
\hline \multirow[t]{2}{*}{$\begin{array}{l}\text { Veracruz de } \\
\text { Ignacio de la } \\
\text { Llave }\end{array}$} & & 8539862 & & 41316 & & 6105 & \\
\hline & Veracruz & 626918 & 7.34 & 8906 & 21.56 & 1142 & 18.71 \\
\hline
\end{tabular}




\begin{tabular}{|c|c|c|c|c|c|c|c|}
\hline & Xalapa - Enríquez & 513443 & 6.01 & 2662 & 6.44 & 434 & 7.11 \\
\hline \multirow[t]{2}{*}{ Yucatán } & & 2259098 & & 25186 & & 2097 & \\
\hline & Merida & 963861 & 42.67 & 15221 & 60.43 & 1175 & 56.03 \\
\hline \multirow[t]{2}{*}{ Zacatecas } & & 1666426 & & 19201 & & 1560 & \\
\hline & Zacatecas & 155533 & 9.33 & 4762 & 20.80 & 305 & 19.55 \\
\hline 95\% C.I. & & & 3.88 & & 5.51 & & 5.44 \\
\hline S.D. & & & 14.49 & & 20.58 & & 20.33 \\
\hline
\end{tabular}

Note. C.I.: Confidence Interval, S.D.: Standard deviation. 


\section{Figure 4}

Thematic maps: Spatial distribution COVID-19 pandemic in Mexico City - population size.

(a) Municipal COVID-19 confirmed cases - population size. ccCOVID-19: Municipal COVID-19 confirmed cases (red circle), hab.: District population. Municipalities of Mexico City. 1: Álvaro Obregón, 2: Azcapotzalco, 3: Benito Juárez, 4: Coyoacán, 5: Cuajimalpa de Morelos, 6:

Cuauhtémoc, 7: Gustavo A. Madero, 8: Venustiano Carranza, 9: Iztapalapa, 10: La Magdalena Contreras, 11: Miguel Hidalgo, 12: Milpa Alta, 13: Tláhuac, 14: Tlalpan, 15: Iztacalco, 16: Xochimilco. (b) Municipal COVID-19 deaths - population density. dCOVID-19: Municipal COVID-19 deaths (purple circle), hab.: District population.

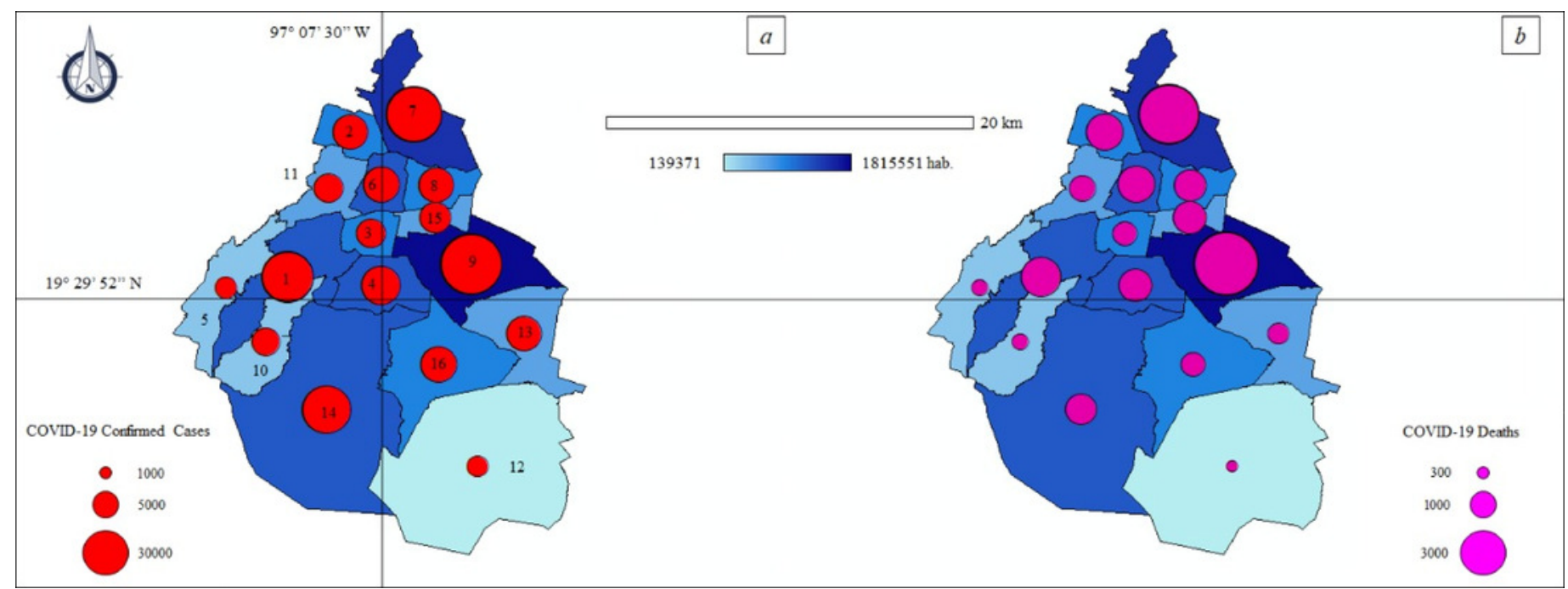


Figure 5

Thematic maps: Spatial distribution COVID-19 fatality rate in Mexico and Mexico City population size.

(a) Mexico. (b) Mexico City.

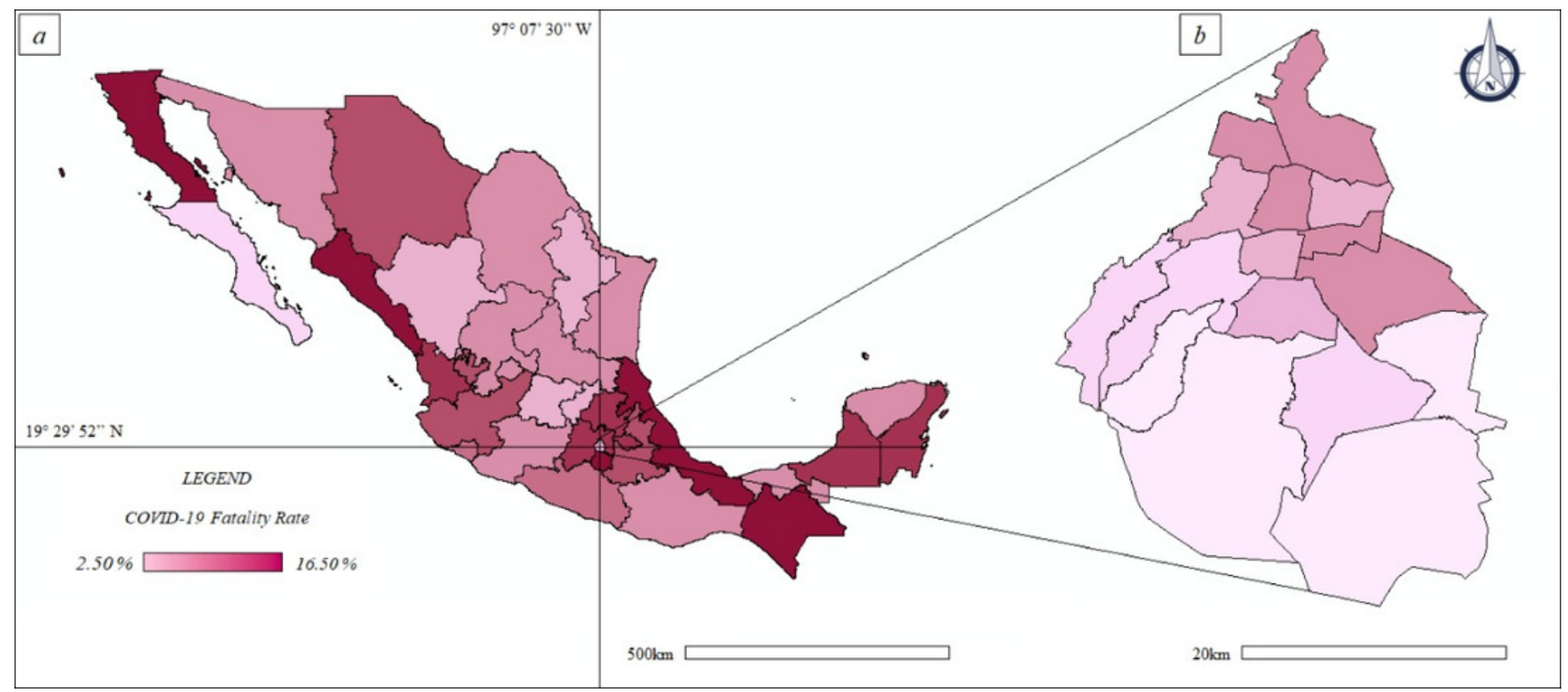


Figure 6

Locally weighted linear regression (LOESS) between studied variables.

(a) Municipal Scale: COVID-19 Confirmed cases - Population size (blue circle), (b) Municipal Scale: COVID-19 Deaths - Population size (purple circle). hab.: Municipal population. 


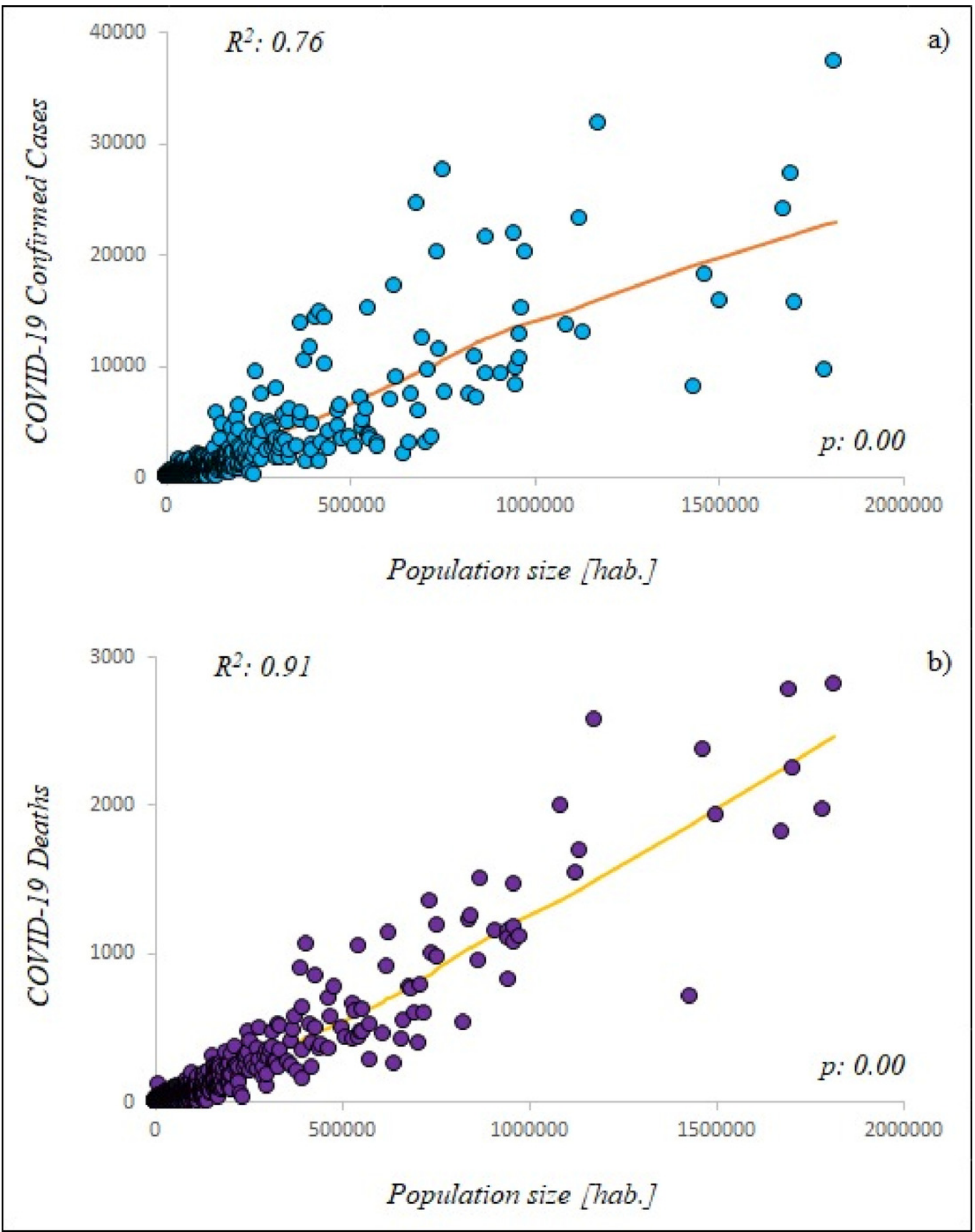

